\title{
How Much Does Political Uncertainty Matter? The Case of Louisiana under Huey Long
}

\author{
Gabriel Mathy and Nicolas L. Ziebarth
}

\begin{abstract}
We study the effect of political uncertainty on economic outcomes using the case of Huey Long's tenure as governor and senator of Louisiana during the Great Depression. Based on primary sources, we construct two well-established measures of uncertainty specifically for Louisiana: stock price volatility and newspaper mentions of terms related to "uncertainty" and the economy. Combining these uncertainty measures with employment data from the Census of Manufactures, we attempt to identify the effects of political uncertainty using the state of Mississippi as a control group. We find little support for a negative effect from political uncertainty in Huey Long's Louisiana.
\end{abstract}

$J^{m+n}$ ust as uncertainty engendered by the political process has been proposed as a cause of the weak recovery from the 2007-2008 crisis, political uncertainty was put forward as a reason for the weak recovery from the 1933 trough of the Great Depression. This view traces back to Joseph A. Schumpeter (1942) and has continued through Robert E. Lucas, Jr. (2011) in the present day. ${ }^{1}$ These authors identified a number of actual and proposed policy changes in the first and second New Deals as potential sources of this uncertainty. For example, Robert Higgs (1997) focused on the second New Deal and argued that there was a widespread fear that property rights were threatened. In a public lecture, Lucas (2011) emphasized the deleterious effects of political uncertainty

The Journal of Economic History, Vol. 77, No. 1 (March 2017). (C) The Economic History Association. All rights reserved. doi: 10.1017/S002205071700002X

Gabriel Mathy is Assistant Professor, Department of Economics, American University, 4400 Massachusetts Avenue, NW, Washington, DC 20016. E-mail: mathy@american.edu. Nicolas L. Ziebarth is Assistant Professor, Economics, University of Iowa, W344 Pappajohn Business Building (PBB), Iowa City, IA 52242 and NBER, 1050 Massachusetts Ave, Cambridge, MA 02138. E-mail: nicolas.lehmannziebarth@gmail.com.

We thank the Berkeley Economic History Lab, a Cole Grant-in-Aid from the Economic History Association, an ALL-UC Graduate Research Grant, and the University of Iowa for funding data collection. Audiences at the Economic History Association, the Bureau of Economic Analysis, and the Washington Area Economic Association mini-conference provided useful comments, as well as Scott Baker, James Fenske, Mary Hansen, Bob Margo, and two anonymous referees. Josh Hausman was crucial in the early stages of the project. Dan Thomas and Daniel Sullivan were indispensable in collecting the images at the National Archives. All errors are our own.

${ }^{1}$ Indeed, at the time of writing, the uncertainty related to Donald Trump's electoral victory is a concern for prominent economists (Summers 2016). 
drawing on quotes from Franklin Delano Roosevelt (FDR) calling businessmen "malefactors of great wealth." While suggestive, Lucas himself admits that well-identified quantitative evidence is lacking on the role of political uncertainty in determining economic outcomes.

Some earlier work by Thomas Mayer and Monojit Chatterji (1985) attempted to identify the effects of confidence and uncertainty using time series variation in investment in the Great Depression by conducting event studies around election results in the New Deal era. Besides this aggregate variation, the Depression provides a number of potentially useful natural experiments in the cross-section to explore this possible relationship. In particular, the Depression saw the rise of a number of politicians, pundits, and policy makers at a local level who, in many cases, went well beyond the "radical" proposals and rhetoric of the Roosevelt administration. Many of the people advocating the most extreme reforms such as Father Charles Coughlin never attained political office. One of those people who actually gained office was Huey P. Long, who became governor of Louisiana in 1928. He continued to run the state essentially unchecked, even after being elected U.S. Senator in 1930, until his assassination in 1935. While the case of FDR's presidency is often cited as a clear example of radical policies engendering uncertainty and retarding recovery (Higgs, 1997), we would argue that Long is potentially an even more extreme example. FDR himself certainly thought so. He viewed Long as one of the two most dangerous men in America, Long being the threat from the left and General Douglas MacArthur being the threat from the right. The president's 1935 "left turn," which included a sharp increase in income and wealth taxes on the top income brackets, drew clear inspiration from Long's "Share Our Wealth" platform (Williams 1981, p. 836). What made Long unique was not only his policies but the way he wielded unchecked power over his state.

We attempt to identify changes in political uncertainty caused by certain actions of Long and to measure the effects of these changes on economic outcomes. There are two key questions in addressing the role of uncertainty. First of all, how do we measure uncertainty, which, by definition, involves (unobservable) beliefs about second moments related to unrealized political or economic conditions? We focus on two methods that have been proposed. The first uses realized second moments of various economic variables to infer what uncertainty was ex ante. For example, a number of authors such as Christina D. Romer (1990), HansJoachim Voth (2002), Nicholas Bloom (2009), and Gabriel Mathy (2016) use the ex post volatility of stock prices as a proxy for uncertainty. Some more recent studies by Sylvain Leduc and Zheng Liu (2012) and Susanto 
Basu and Brent Bundick (2012) use implied volatility measures from options such as the VIX or the VOX index. The second approach, which one might call the narrative approach, has attempted to quantify the amount of discussion of uncertainty in the popular press. For example, Michelle Alexopoulos and Jon Cohen (2009) count the number of articles in the New York Times that mention terms related to "uncertainty" and "economy" as such a measure. In a closely related article, Scott R. Baker, Bloom, and Steven J. Davis (2015) construct a similar measure of political uncertainty restricting attention to articles with terms involving the economy, uncertainty, as well as policy-related terms like "taxes" and "deficits."

We will apply these two approaches to measure political uncertainty for the specific case of Huey Long's Louisiana by constructing a stock return volatility measure using Louisiana-based stocks listed on the New Orleans Stock Exchange (NOSE) and on the New York Stock Exchange (NYSE). In addition, we construct a newspaper index based on the number of articles in the Louisiana paper of record, the New Orleans Times-Picayune (NOTP), that mention "uncertainty" and terms related to the economy. This period of history in Louisiana did not in any way lack for the possibility for unexpected and uncertain developments, ranging from the special tax Long attempted to have imposed on Standard Oil in 1929 to the takeover of a courthouse in Baton Rouge by a paramilitary organization opposed to Long in 1935. Our first finding is that, while there are spikes in the uncertainty measures relative to a national measure, only rarely can we identify Long-related events that correspond to these spikes. This contrasts with the related literature such as the paper by Bloom (2009), which found a close correspondence between major political events like JFK's assassination and the Cuban Missile crisis and uncertainty shocks as measured by spikes in stock volatility.

The second question, putting aside the question of how to measure uncertainty, is how to identify the causal effects of these measured changes in uncertainty. Recessions themselves may generate increases in political uncertainty endogenously, reversing the standard direction of causality from increases in uncertainty to declines in investment and output. Lubos Pastor and Pietro Veronesi (2012) provide a formal model precisely of this direction of causality with slow growth leading to political uncertainty due to an increased demand for policy experimentation. It is not a stretch to interpret much of the New Deal as a direct response to the collapse in the aggregate economy. Because of this endogeneity concern, we use a difference-in-differences strategy to identify the effects of political uncertainty using the bordering state of Mississippi 
as a control group. We use establishment-level employment data from the Census of Manufactures. Besides providing higher frequency variation, these data allow us to examine the heterogeneity in the effect across different plant sizes and industries. They also permit the use of within state geographic variation to identify the effects by focusing on counties along the state border as in Thomas J. Holmes (1998).

Like Mayer and Chatterji's previous work at the aggregate-level, we find little evidence that uncertainty resulting from Long mattered for employment in Louisiana manufacturing establishments. Estimated effects are small in magnitude and statistically insignificant. This is true whether we use the full sample or restrict our attention to border counties. Our results are particularly striking because the treatment-control framework we use, if anything, would tend to overstate the aggregate equilibrium effects. Part of the measured effect may simply be a reallocation of economic activity from Louisiana across the border to Mississippi, which would cancel out in the aggregate. This contrasts with many of the other results in this literature that find significant effects of uncertainty, such as the papers by George Bittlingmayer (1998), Baker and Bloom (2013), and Daniel Shoag and Stan Veuger (Forthcoming). This might lead one to ask: Why didn't uncertainty matter in Huey Long's Louisiana?

One explanation for the null result is that the uncertainty measures we construct are not really reflective of "true" changes in uncertainty. To allay this concern, we supplement our regression results with event studies for a number of significant events related to uncertainty. This provides an alternative way to measure uncertainty shocks. Following a large literature from financial economics surveyed in John Binder (1998), we examine excess returns of Louisiana based stocks listed on the NYSE on the days of the selected events. We again find little effect from these major political events. We also study the effects of Long's assassination in September 1935 on employment using our treatment-control framework. We first provide narrative evidence and some direct evidence from financial markets that Long's death was marked with relief by businesses in the state. For example, the prices of Louisiana state government bonds rose after his death with market participants relating it to that singular event. With this evidence for an exogenous decline in uncertainty, we examine the effects on employment again using Mississippi as the control group. In almost all specifications, we find a null effect.

What these overall null results for Long's assassination obscure is the heterogeneity in the effects across establishment sizes. In fact, we find some evidence that the largest establishments prospered under Huey Long relative to the smallest ones. This is rather ironic given Long's populist 
demonization of big business like Standard Oil. When Long was assassinated, the differential effects on these groups of establishments tend to offset each other, thus muting the overall effect. There is some anecdotal evidence that the largest plants were best able to navigate Long's system of kickbacks required to bid on all sorts of government projects. Like the study of the English East India Company by Dan Bogart (2015), these results show the costs and benefits of cozying up to leaders with extraordinary power.

In this work, we distinguish between economic as opposed to political uncertainty, our topic of interest. Political uncertainty is driven by just that, political factors such as changes in future tax rates. On the other hand, economic uncertainty is uncertainty over more general economic fundamentals like productivity or demand. For example, Romer (1990) argues that economic uncertainty caused by the 1929 stock market crash can explain the decline in consumer durables consumption in late 1929 and 1930. Following that work, Mathy (2014) uses a vector autoregression (VAR) approach to identify additional support for this channel. J. Peter Federer and David A. Zalewski (1994) argue for interest-rate uncertainty as a channel through which banking crises and the collapse of the international gold standard in the Depression had negative impacts on the real economy. For modern business cycles, Bloom et al. (2012) and Fernández-Villaverde et al. (2011) find large negative effects of economic uncertainty with contrasting studies such as Benjamin Born and Johannes Pfeifer (2011) finding little effect.

\section{HISTORICAL BACKGROUND ON LONG'S POLITICAL CAREER}

Huey Long's political ambition was evident early in his life when, while still in high school, he openly boasted that he would ascend to the American presidency after passing through the offices of Governor and Senator of Louisiana (Williams 1981, p. 39). Major events in Long's career are outlined in Figure 1. After working as a traveling salesman and lawyer, Long began his political career by winning the election to the Louisiana Railroad Commission in 1918. From the beginning of his political career, he campaigned on a populist platform, telling crowds in his first campaign for public office that his opponent was a tool of big business (Hair 1991). Previous commissioners tended to intervene little and to largely acquiesce to the wishes of the businesses they regulated (Hair 1991). Long, however, used his post to launch populist attacks on Standard Oil, Louisiana's largest oil company and his lifelong enemy. He called the company an "octopus" and "highway bandit" (qtd. in Hair 


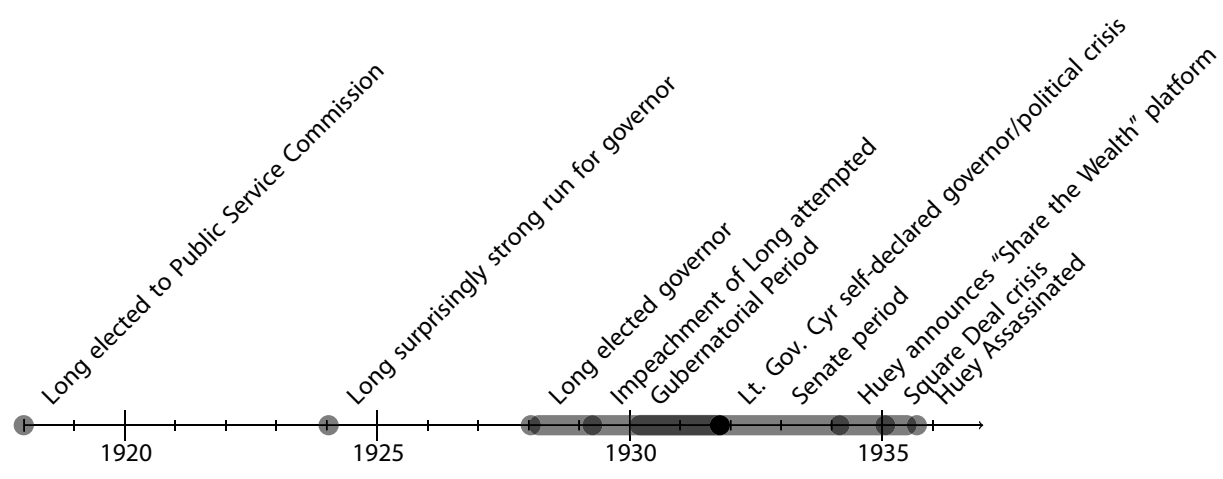

FIGURE 1

CHRONOLOGY OF MAJOR POLITICAL UNCERTAINTY EVENTS RELATED

TO HUEY LONG

Source: See text for description of events.

1991, p. 92), and demanded that the incumbent governor work with the legislature to declare oil pipeline companies public utilities so they would be subject to more extensive regulation.

In 1924, Long ran for the Democratic nomination for governor and lost. Long had little press support and few Louisiana power brokers backed him (Hair 1991). However, he did score a surprising third place finish, which was an indicator of his future political successes. Long ran again in 1928 with more political experience, a better developed political organization, and more favorable circumstances. Campaigning under the slogan, "Every man a king but no one wears a crown," Long's campaign promises included a program to provide free textbooks for school children as well as a bond-financed road and free bridge building program. He won.

Almost immediately after becoming governor, Long began consolidating political power by firing political opponents and forcing state employees to make monthly contributions to his political machine (White 2006). Furthermore, while Long did not invent the use of patronage to amass power, he did perfect it into an art form. His system of patronage began with his first legislative session as governor. To assemble enough votes to pass his free textbook and road building bills at least 16 legislators were given "deadhead" jobs on the state payroll. Those legislators already on the payroll were told to "get right" or risk losing their job (Hair 1991). Everyone from Long henchmen like Oscar Allen to lowly appointees were required to sign undated letters of resignation to be brought out in case they deviated from his wishes. A system of "deducts" required state employees to contribute part of their salary to his political 
machine. The Long machine extended its reach by demanding kickbacks from state contractors.

Long started implementing his program aggressively in his first months as governor. He immediately passed a new tax on gasoline to fund his road and bridge program. To enact the free schoolbooks program, Long reorganized and raised the severance tax on natural resource production in Louisiana. The severance tax had been enacted by a previous governor, but Long's changes had the effect to tax the oil and gas industry more heavily. He also instituted a tax specifically on the carbon black industry, continuing a pattern of targeting politically unpopular industries (Williams 1981, pp. 305-10). Long, riding high on his earlier successes, included in his proposals for the 1929 legislative session proposed legislation which shocked his supporters but even shocked the opposition. In particular, he proposed an occupational tax on oil refining. Standard Oil saw this as a direct attack on their refinery in Baton Rouge, and Long admitted that his main intent for this bill was to tax his old nemesis from his days as a trial lawyer. Many of his supporters were opposed to his proposal, and it galvanized the opposition. Within days of the proposal, impeachment proceedings were underway against Long.

The tenor of this unruly legislative session can be seen in the events of 25 March 1929, which came to be known as "Bloody Monday." It started when a voting machine malfunction was mistaken for a rigged vote by opponents of Long. As legislators rushed the podium, a fistfight broke out and blood was drawn on the floor of the Louisiana senate (Williams 1981, p. 347-83). After a wild debate by both pro-Long and anti-Long forces to win the vote by any means necessary (including bribery and intimidation), Long was able to secure a signed commitment by enough legislators that they would vote against impeachment no matter the charges.

After two years in office as governor, Long won a seat in the U.S. Senate. However, rather than moving to Washington and vacating the governor's seat in Louisiana, Long decided to postpone becoming senator until a loyal successor could be installed as governor. In keeping with the rapidly shifting alliances that had characterized Louisiana politics, he had a falling out with his lieutenant governor over a death sentence given to a couple convicted of murder (Williams 1981, p. 336-39). On 13 October 1931, lieutenant governor Paul Cyr declared himself governor, arguing that Long had given up his seat when he was elected U.S. Senator. In a scenario that could have played out in any number of banana republics, Long mobilized the National Guard to defend the capitol and Governor's mansion from being seized by the insurgent Cyr (Hair 1991). 
In the 1932 gubernatorial primary, Long backed his hand-picked replacement, Oscar Allen, to replace Cyr. Allen was a Long loyalist and he won a landslide victory backed by the Long machine, aided by brazen vote fraud in some parishes. For example, St. Bernard parish delivered 3,152 votes to Allen and zero votes to the two other candidates, despite having only 2,194 registered voters (Hair 1991). With Oscar Allen as governor of Louisiana, Long was able to maintain and even increase his power in the state after taking up his position in the U.S. Senate. Allen essentially took orders from Long (White 2006; Williams 1981), and Long probably forced Allen to give him a signed, undated letter of resignation in case his loyalty ever wavered (Hair 1991). Earl Long, Huey's brother, described Allen's obedience thusly: "A leaf once blew in to Allen's office and fell on his desk. Allen signed it" (Schlesinger 2003, p. 58). Long continued to occupy the governor's office when in Baton Rouge and sometimes made appearances on the floor of the legislature. On one occasion the legislature passed 44 of Long's bills in just 22 minutes (Schlesinger 2003, p. 58).

Huey's consolidation of power reached its zenith in 1934. First, he reduced the power of local governments, which hurt the Old Regulars, a ring of sheriffs and other New Orleans leaders who were the most stubborn and persistent Long opponents (Williams 1981). He passed a tax on newspapers, which he called a "tax on lying." In 1934, Long strengthened the Bureau of Criminal Identification, an agency empowered to make warrantless arrests throughout Louisiana (Hair 1991). In early 1935, in reaction to Long's consolidation of power, a coalition including a former Louisiana governor and the mayor of New Orleans organized a paramilitary organization, the Square Deal Association (Hair 1991). They took over a courthouse in Baton Rouge in January 1935, leading Long to call out the National Guard and impose martial law. Baton Rouge newspapers were prohibited from criticizing the state government (White 2006). In addition, the Long government infringed on the right to bear arms, muzzled press criticism of the state government, and limited the right to assemble (Williams 1981, p. 787). Even after the spasm of violence in 1935, Long continued his assault on the press with a state printing board that could withhold "official printer" status from newspapers. He also created a new board of election supervisors to watch polls, essentially guaranteeing the election of Long's chosen candidates regardless of their actual popular support (Hair 1991).

His reign came to an abrupt halt when Carl Weiss, enraged that his father-in-law, a Long opponent, would lose his judgeship due to Long's 
gerrymandering, shot and killed Long on 10 September 1935 as he walked through the Louisiana state capitol. This quickly spelled the end of an era. The New York Times (11 September 1935, p. 16) quoting from The Sun (Ind. Rep.) summarized the situation:

The death of Huey Long should have important political consequences. In Louisiana, where the Senator has dominated the State in as bold a manner as ever was observed in American politics, his passing from the scene means a struggle among his followers to hold his power, but none of his adherents possesses the ability or the nerve of the dictator who has just succumbed to the bullet of an assassin. Possibly with Long out of the way the forces which have vainly struggled to restore Louisiana to a genuine republican form of government will be able to push forward to victory.

The situation was even more succinctly summarized by the New York Times (29 September 1935, p. E7) who published an article entitled "Louisiana Sees Wane of the Dictatorship."

Long, at the time of his assassination in 1935, controlled the legislative, judicial, and executive branches in an unprecedented dominance of one American state's government (Williams 1981, p. 6). Even the Old Regulars who controlled New Orleans had been brought under Long's thumb by the time of his assassination (Williams 1981, p. 853). His rhetoric and nearly dictatorial control over the state seemed at times almost intended to frighten business and generate uncertainty about future policy. For example, from the Wall Street Journal of 16 December 1935, p. 15:

Although Louisiana's fiscal policies in the past decade or so have not caused the state any financial embarrassment and have actually been more conservative than those of some other states, the uncertainty which Senator Long's political control engendered has cost the state considerable money in additional interest charges on its debt.

T. Harry Williams (1981, p. 185), in his seminal Long biography, goes so far as to compare Long to a caudillo, a term reserved for leaders of Latin American banana republics. Long's first biography referred to him as a "Tinpot Napoleon," (Fineran 1986), and like the French dictator, whose biography was a favorite of Long's (Williams 1981, pp. 21, 34), Long would crown himself with the nickname "Kingfish," a telling choice reflecting Long's monarchical ambitions (Williams 1981, p. 313). He had long respected and admired the political skill of Henry Clay Warmoth, the carpetbagger governor of Reconstruction Louisiana who wielded absolute power to pass progressive legislation over the objection of the Louisiana elites (Williams 1981, pp. 184-85). The parallels 
with Long's political career are unambiguous. One Long opponent said to him, "Maybe you've heard of this book. It's the Constitution of the State of Louisiana." Long replied, "I'm the Constitution around here now" (Schlesinger 2003, p. 47). Leading contemporary fascist thinkers like Lawrence Dennis saw Long as an ideal candidate to lead an authoritarian America (Schlesinger 2003, p. 77).

\section{MEASURING POLITICAL UNCERTAINTY}

A major issue with measuring uncertainty is that expectations about future outcomes cannot be directly observed and must be inferred. For this reason, several measures have been developed as proxies for the true underlying level of uncertainty. Bloom (2009) outlines several such measures including the cross-sectional standard deviation of firm profit growth, firm-level stock returns, industry-level productivity growth, and disagreement in gross domestic product (GDP) forecasts by professional forecasters. We will focus on stock price volatility and newspaper mentions of the word "uncertainty."

\section{Realized Stock Volatility}

Following a literature going back to G. William Schwert (1989), we construct a stock price index for the NOSE using stock quotes compiled from New Orleans' The Times-Picayune newspaper from 1922 through 1937. Quotes are available on trading days during the workweek excluding holidays with prices quoted for both the morning and the afternoon. The NOSE listed mainly Louisiana stocks, but did cross-list some stock with major operations elsewhere in the South. We have attempted to separate these two groups as presumably the Louisiana-based corporations would be more sensitive to Long's policies. ${ }^{2}$ Stock returns were then calculated as the $\log$ difference between daily stock prices ex dividend, and the overall index is an equal-weighted average of individual stock's returns. ${ }^{3}$ Stock volatility is then calculated as the monthly standard deviation of

\footnotetext{
${ }^{2}$ The stocks traded on the NOSE are listed in the Online Appendix as well as whether we classified them as a Louisiana company. A company was classified as primarily Louisiana-based by using Moody's reports which discuss the primary business of these companies and their locations. If both morning and afternoon bid or ask quotes were present, we used the average bid or ask spread. If only one of the sessions was present, we used that quote only. The bid and ask spreads were then averaged to get the price for that stock. If any bids or asks were missing, the values were interpolated from values that were available.

${ }^{3}$ Unfortunately, it is difficult to gather information on dividends as well as information on market capitalization to construct a weighted market index for volatility that includes dividends.
} 
daily returns. To be sure, this measure will not distinguish between political and economic uncertainty like the newspaper measure.

Both the level and the volatility of all stocks and Louisiana-based stocks on the NOSE are shown in Figure 2. Major uncertainty-related events related to Huey Long are highlighted as well. These include January 1928 when Long won the Democratic primary for governor; April 1929 when he proposed to target Standard Oil and his subsequent impeachment trial; October 1931 when Vice Governor Cyr declared himself governor sparking a political crisis; February 1934 when Long announced his "Share Our Wealth" program; January 1935 when "Square Dealer" groups armed themselves and threaten to unseat Long; and September 1935 when Long is assassinated. It is hard to see much of a relationship between these events and spikes in either direction in stock returns in Panel (a). Turning to volatility in Panel (b), similar to Bloom (2009), we see some correspondence between the events and spikes in uncertainty. For example, when Cyr declared himself governor, there is a clear spike as well as during the Square Deal Crisis. However, as shown in Panel (c), when comparing the relative volatility of these Louisiana stocks listed on the NYSE to the overall volatility of the S\&P 500, the Louisiana stocks appear to have a lower volatility relative to the overall market, which points towards a small overall effect.

\section{Newspaper Index}

Our second measure is an index of the number of times terms related to uncertainty and the economy are mentioned in newspapers' articles. This was originally proposed by Alexopoulos and Cohen (2009) to study economic uncertainty and extended by Baker, Bloom, and Davis (2015) to focus on political uncertainty. The original index used the number of mentions of either the words "economic" or "economy" and "uncertain" or "uncertainty" to quantify sentiment regarding economic uncertainty. This measure was modified to measure political uncertainty by Baker, Bloom, and Davis (2015) through the addition of other terms such as "Congress," "legislation," "White House," "regulation," "Federal Reserve," or "deficit." We construct a similar measure using the New Orleans Times-Picayune, the newspaper of record for the state of Louisiana. We performed a search for the terms "economic" or "economy" and "uncertain" or "uncertainty," which then yields article counts per month. The number of articles are then divided by the total days in that month to obtain an average number of article "hits" per month. Because of possibly different terminology used to describe the economy of the time, we also construct a newspaper uncertainty index using "commerce" 


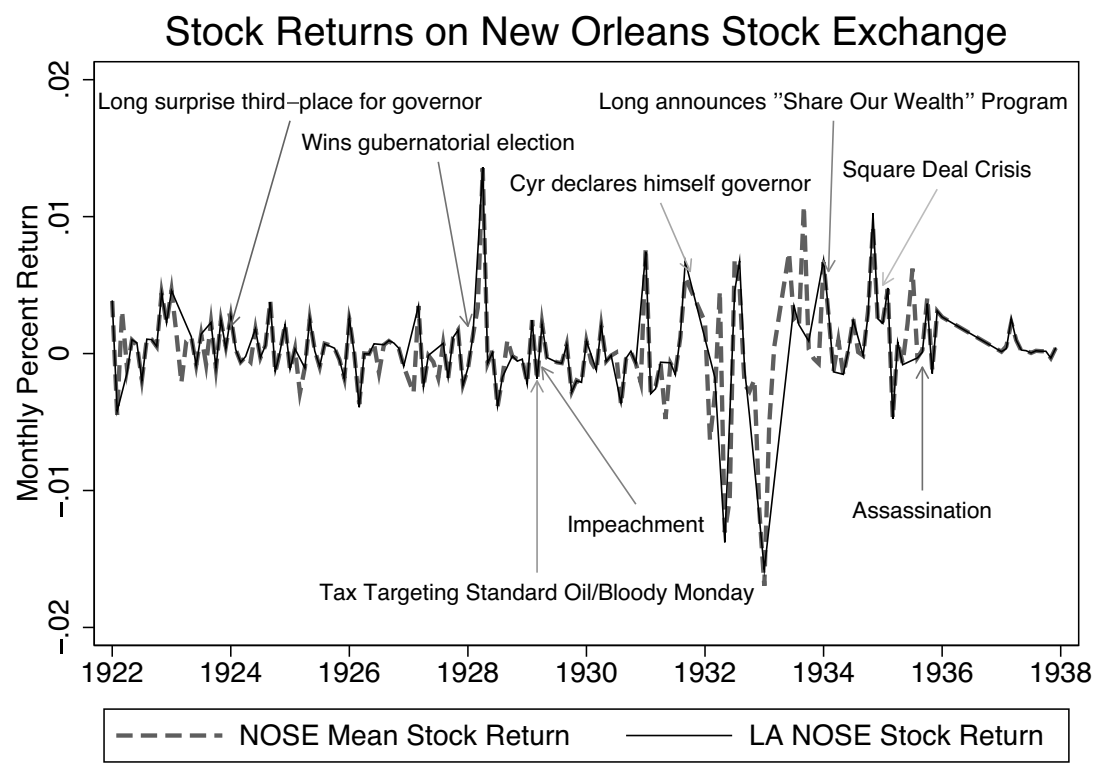

(a)

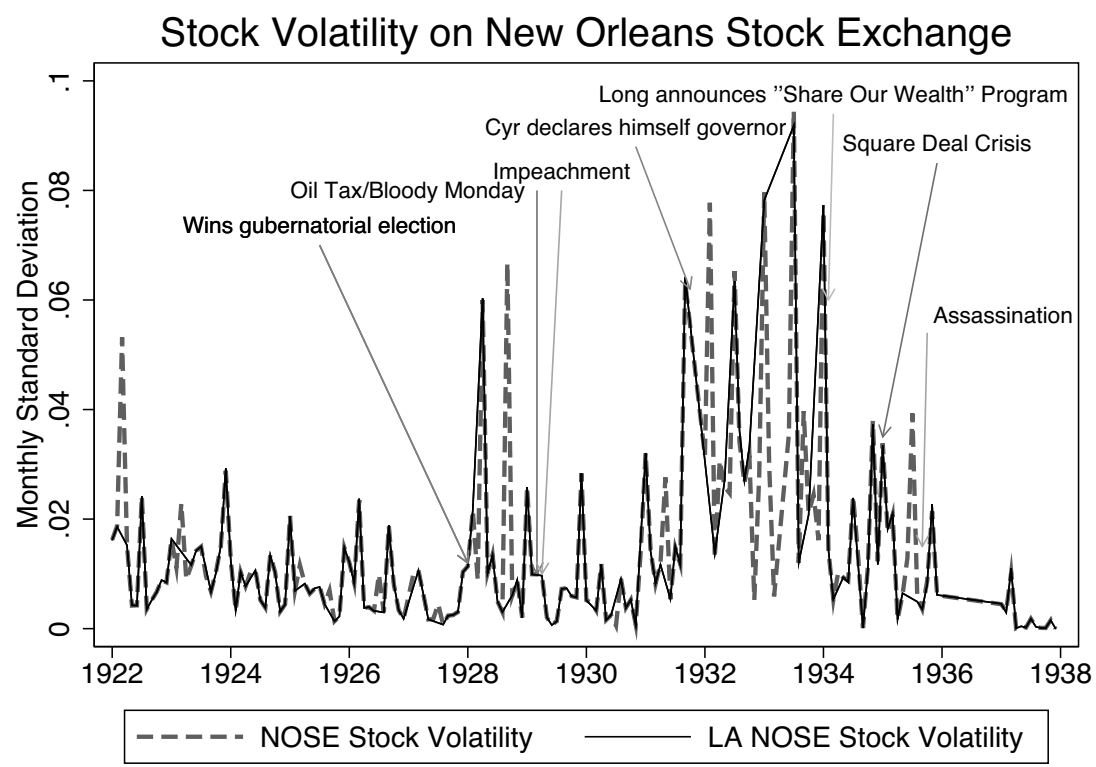

(b)

FIGURE 2

STOCK PRICE AND VOLATILITY SERIES

Notes: Panel (a) is the monthly return on New Orleans Stock Exchange, calculated as the log difference between the NOSE stock index between one month and the previous month. Panel (b) is monthly stock index volatility calculated as the monthly standard deviation of daily log returns for NOSE index. Louisiana stocks refer to the stock index which is only composed of Louisiana companies.

Sources: New Orleans Times Picayune and Center for Research on Security Prices (CRSP). 


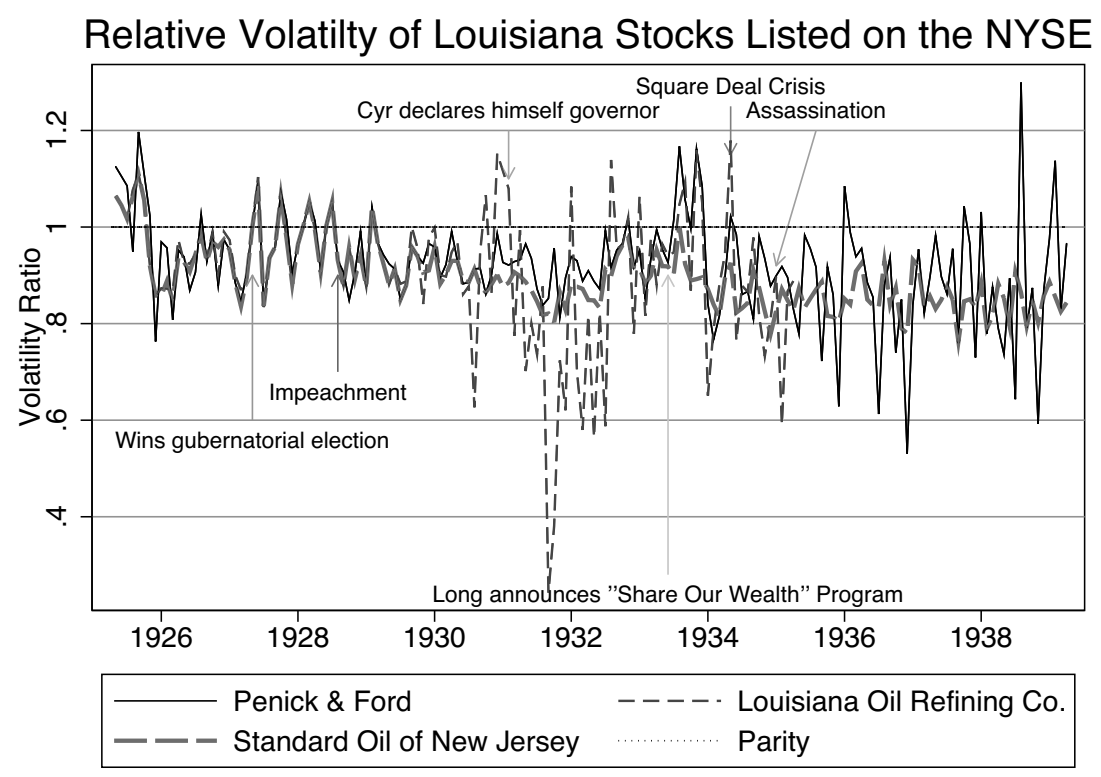

(c)

FIGURE 2 (CONTINUED)

STOCK PRICE AND VOLATILITY SERIES

Notes: Panel (c) is for Louisiana based stocks on NYSE. These include the Louisiana Oil Refining Company, Penick \& Ford, and Standard Oil of New Jersey (which had major operations in Louisiana).

Sources: New Orleans Times Picayune and Center for Research on Security Prices (CRSP).

or "commercial" rather than "economic" or "economy." Due to the large amount of high-frequency movements, we apply a Baxter-King (BK) filter (Baxter and King 1999) to smooth the data. ${ }^{4}$ To assuage concerns that the BK filter uses not just lags of the series but also leads, we have also calculated a six month moving average constructed with five lags and the current month with little difference in the results.

Figure 3 plots these two series using "economic" or "commercial" terms in conjunction with "uncertainty" terms as the keywords. The period when Long is in power between the black lines does see somewhat elevated uncertainty, but uncertainty does not fall significantly after Long's unexpected demise in 1935. Furthermore, it would be difficult to relate the spikes in newspaper mentions to any of the events that we highlighted in discussing the stock price measure. The newspaper uncertainty index seems to be measuring something similar to the stock volatility index. The correlation is 0.43 at a monthly frequency.

\footnotetext{
${ }^{4}$ Following the recommendations of Baxter and King (1999), the band is between 18 and 96 months.
} 


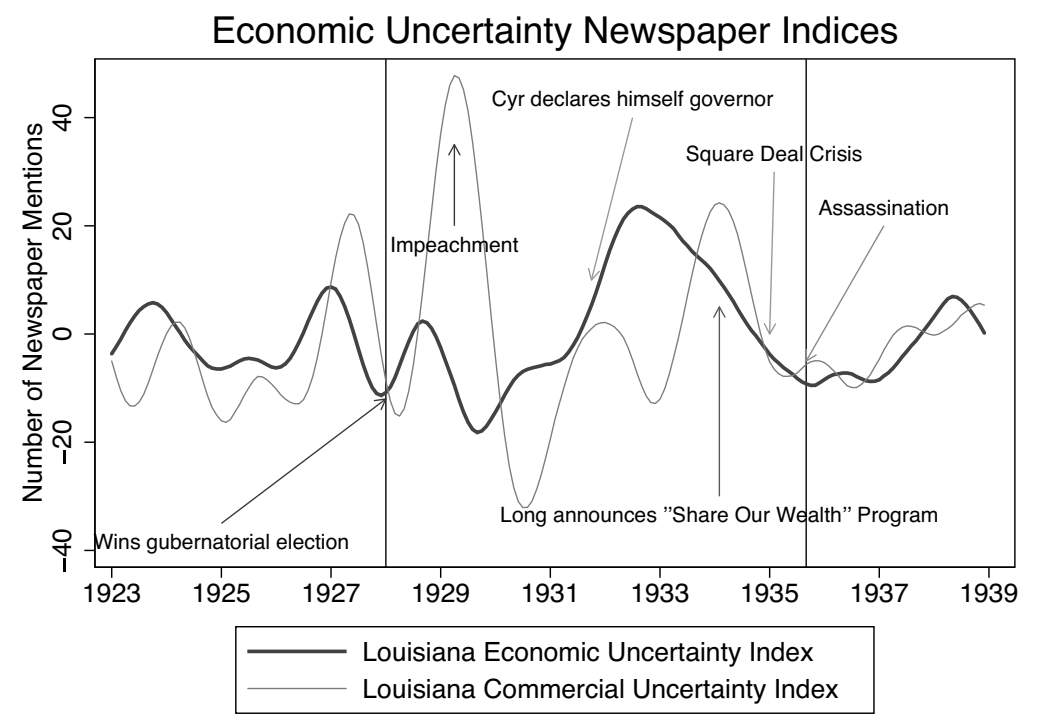

(a)

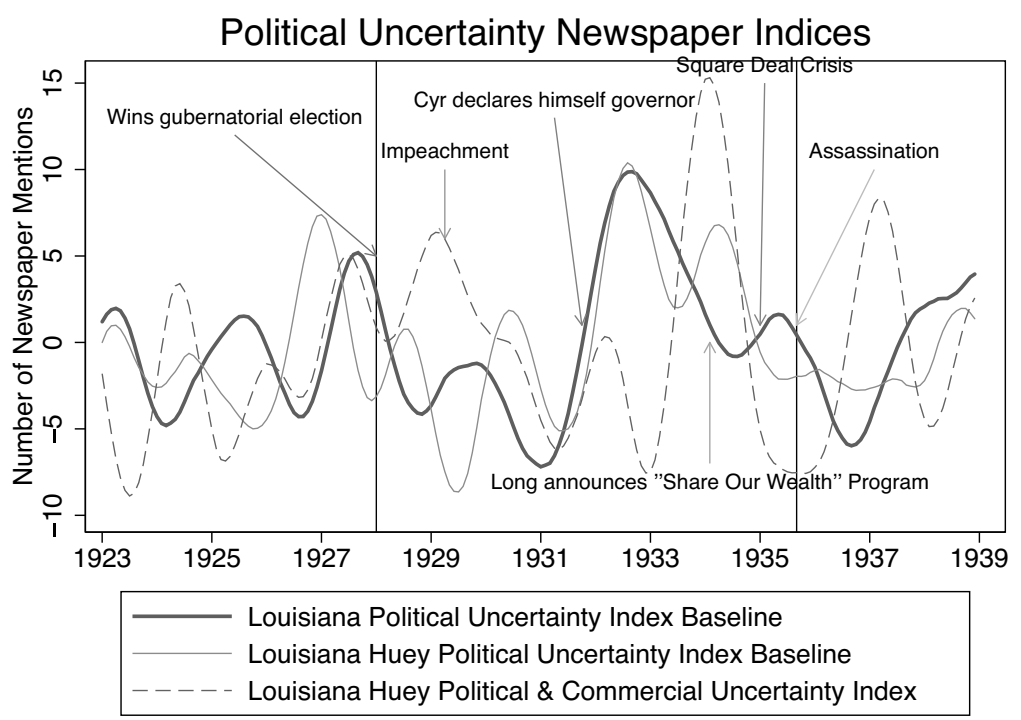

(b)

FIGURE 3

NEWSPAPER UNCERTAINTY MEASURES

Notes: Panel (a) is calculated using the number of monthly article mentions of "economic uncertainty" in the New Orleans Times Picayune (NOTP). The Louisiana Commercial Uncertainty Index replaces the term "economic" with "commercial." Panel (b) displays an extended index including the terms "tax" or "oil" or "impeachment" or "Share our Wealth" or "Square Deal" in the NOTP. The Louisiana Huey Political Uncertainty Index is based on the terms "Huey" or "Long" or "Kingfish." The Louisiana Huey Political \& Commercial Uncertainty Index is formed using the number of monthly article mentions of "commercial" instead of "economic." All series are smoothed using a Baxter-King band-pass filter. Black lines indicate Long's tenure as governor or senator.

Sources: New Orleans Times Picayune and The New York Times. See the text for more details. 


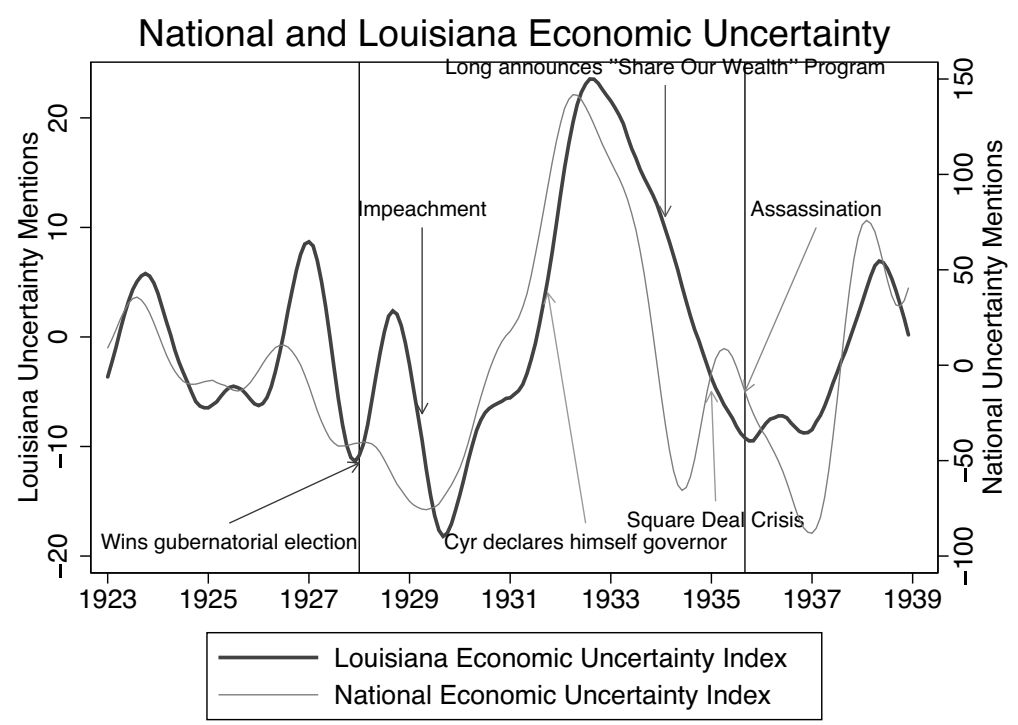

(c)

\section{FIGURE 3 (CONTINUED) \\ NEWSPAPER UNCERTAINTY MEASURES}

Notes: Panel (c) displays the Louisiana Economic Uncertainty Index formed using the number of monthly article mentions of either the words "economic" or "economy" and "uncertain" or "uncertainty" in the NOTP. The National Economic Uncertainty Index uses the same search terms but searches The New York Times. All series are smoothed using a Baxter-King band-pass filter. Black lines indicate Long's tenure as governor or senator.

Sources: New Orleans Times Picayune and The New York Times. See the text for more details.

We construct another index based on additional terms related to either Long or his policies using terms related to the uncertainty events we have outlined earlier. As reported in Panel (b), the first measure adds in the requirement that one of the terms "tax," "oil," "impeachment," "Share our Wealth," or "Square Deal" must be present alongside the baseline terms. The second specification again uses the economic uncertainty terms but now adds in either "Huey" or "Long" or "Kingfish" to see if Huey Long is mentioned in conjunction with uncertainty. The third specification uses the terms from the first specification with the commercial terms replacing the economic terms in the search to see if commercial terms rather than economic terms generate different results.

Finally, given that the Times-Picayune reports on national issues as well as local issues, uncertainty at the national level may be driving the increase in uncertainty mentions in the newspaper. To address this concern, we performed a similar search using the New York Times to derive a baseline level of uncertainty for the aggregate U.S. economy. Panel (c) plots both of these series and shows most convincingly the 
relative effect of Huey Long in generating political uncertainty in Louisiana. While the Louisiana specific index does rise during the early 1930s, the national index also rises at the same time, reflecting general national uncertainty in the early 1930s (Mathy 2014). The Louisiana paper of record was reporting on uncertainty, but it was not uncertainty stemming from Huey Long's policies. If anything, given that the TimesPicayune was also a vociferous Long opponent, it would be more likely to report on events casting Long's actions in a less than flattering light. Unlike the stock volatility index, it is difficult to identify spikes in the uncertainty measure. Changes in the Louisiana based measure seem to be driven almost totally by changes in the aggregate uncertainty measure.

\section{ESTIMATING THE EFFECTS OF POLITICAL UNCERTAINTY}

Our data source is the establishment-level records from the Census of Manufactures (CoM) for 1929, 1931, and 1935. Nicolas L. Ziebarth (2015) provides an extended discussion of the source for the interested reader. Our dependent variable is monthly employment of wage earners. Every establishment was asked to report the "Number of wage earners who worked during any part of a week of normal activity in each month [in the calendar year], preferably the week ended nearest the 15th day of the month." One of the most pressing issues in working with these records is the coverage of establishments. We have cross-checked our totals for 1929, 1931, and 1935 with the published Census volumes with very good correspondence. There appears to be some missing data for 1933 with over 800 establishment-level returns unavailable. For this reason, we have excluded 1933 from our main specification. ${ }^{5}$ We estimate a difference-in-difference specification using the manufacturing establishments in Mississippi as a control group. ${ }^{6}$ Louisiana and Mississippi were fairly similar in the structure of their economies and level of development at the time. Both Mississippi and Louisiana were predominantly rural states with underdeveloped manufacturing sectors, some fishing related industry, and a long common border. Mississippi was slightly more rural and poorer, but the differences do not seem important. For example, Mississippi had an income per person in 1929 of \$286, while Louisiana had an income per capita of $\$ 414$, both far below the American average of $\$ 700$ (U.S. Department of the Census 2003). These differences are summarized in Table 1. Besides these economic similarities, these states

\footnotetext{
${ }^{5}$ In the Online Appendix, we show our results are robust to including the observations from this year.

${ }^{6}$ Ziebarth (2013) collected all the establishment data for Mississippi for a separate project on the effects of bank failures.
} 
TABLE 1

COMPARING LOUISIANA TO MISSISSIPPI

\begin{tabular}{lcccccc}
\hline \hline & $\begin{array}{c}\text { Pop. } \\
\text { Density }\end{array}$ & Population & $\begin{array}{c}\text { Percent } \\
\text { Black }\end{array}$ & $\begin{array}{c}\text { Percent } \\
\text { Rural }\end{array}$ & $\begin{array}{c}\text { Ave. Farm } \\
\text { Size }\end{array}$ & $\begin{array}{c}\text { Per Capita } \\
\text { Income }\end{array}$ \\
\hline Louisiana & 52.32 & 2.36 & 36 & 59 & 63 & 288 \\
Mississippi & 46.05 & 2.18 & 49 & 80 & 61 & 173 \\
\hline
\end{tabular}

Notes: Average farm size is measured in acres, population in millions, and per capita income is in nominal dollars.

Sources: The first five variables are from Sutch and Carter (2000) and the sixth is from the BEA. The first four variables are from the 1940 census and the fifth and sixth are from 1935.

share similar temperature patterns though Louisiana has a rainy period from May to July not present in Mississippi as reported in Figure 4. We control for possible seasonal differences in our specification. In addition, the states share a long, common border, which we will exploit in a more stringent comparison of establishments close to either side of this boundary.

We assume that employment for plant $i$ in industry $k$ at time $t$ in state $s$ can be written as

$$
\begin{aligned}
\log E_{i s t} & =\beta_{0}+\beta_{1} \text { Uncertainty }_{s t}+\sum_{s, t} \gamma_{s t} L A_{s}^{*} \text { Month }_{t} \\
& +\sum_{t} \delta_{t} \text { Year }_{t}+\sum_{k} \omega_{k} \text { Industry }_{i, k}+\varepsilon_{i k s t},
\end{aligned}
$$


its value to 0 for establishments in Mississippi. We experiment with including the Louisiana uncertainty measured normalized by a national measure of uncertainty. In this baseline setting where we do not normalize by an aggregate series, if there were common changes in uncertainty in Mississippi and Louisiana (or other aggregate shocks for that matter), they will be captured by the full set of common year dummies $\Sigma_{t} \delta_{t} Y_{\text {Year }}$. We also include state specific seasonal trends $\Sigma_{s, t} \gamma_{s t} L A_{s} *$ Month to control for possible differences in the agricultural cycles of the two states and $\Sigma_{k} \omega_{k}$ Industry ${ }_{i, k}$ is a full set of industry fixed effects. We also report results using $\Delta \log E_{i s t}$ as the dependent variable. We have also run this specification aggregating to the quarterly level to smooth out some of high frequency fluctuations potentially due to measurement error with little effect on the estimated effects, so we do not report these results here. We report robust standard errors while standard errors clustered at the year-month-state level are basically no different.

There are a number of issues in the interpretation of these regressions. First, to interpret these estimates as causal, a crucial assumption 


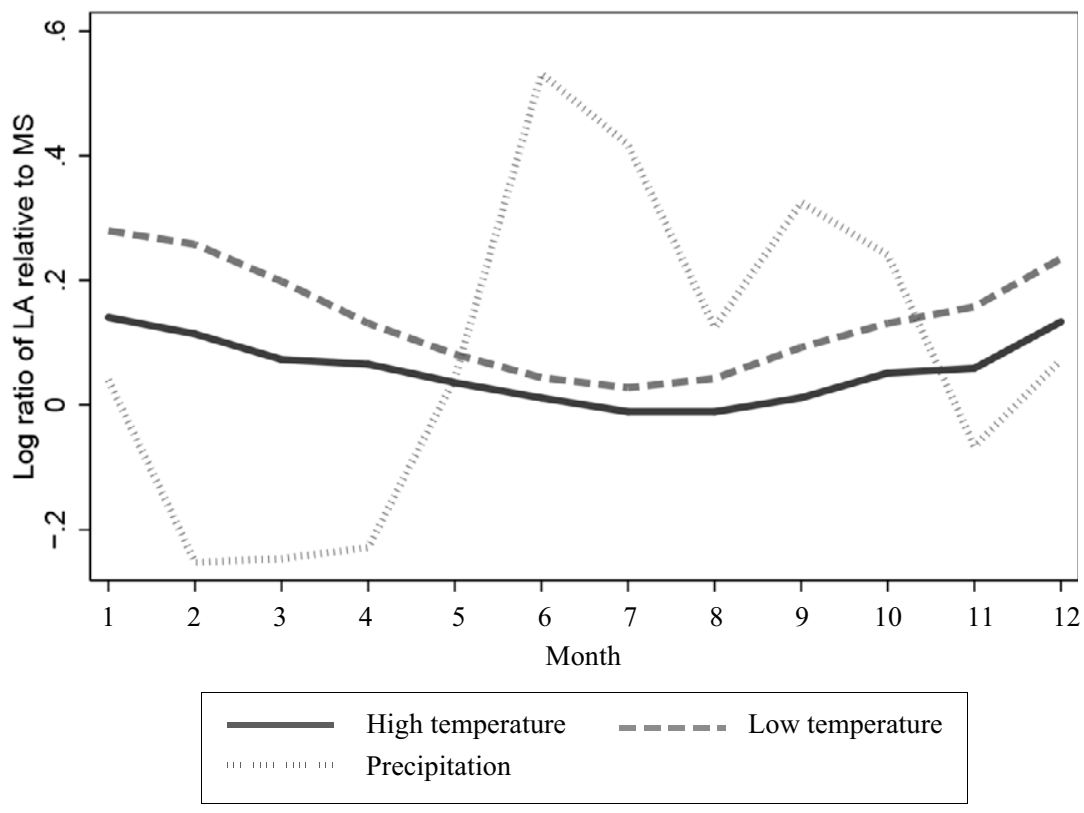

FIGURE 4

COMPARISON OF LOUISIANA AND MISSISSIPPI CLIMATES

Source: weather.com.

is that the control group is not affected by the treatment. While impossible to completely rule out, the available evidence suggests that Long had little influence in Mississippi and certainly no power comparable to that which he wielded in Louisiana. A secret poll conducted in 1935 by the Roosevelt administration to assess popular support for Long found that only 10.5 percent of respondents in Mississippi said they would vote for Long rather than FDR or a Republican candidate for president. This was only slightly higher than the national average of 7.4 percent and far below Long's 36.1 percent support in Louisiana (Amenta, Dunleavy, and Bernstein 1994). At the same time, Long did attempt to intervene in the political business of other states. Announcing that he was going to "invade Arkansas," Long supported the successful campaign of Hattie Caraway, the first female governor of Arkansas (Williams 1981, p. 583-93). He even proposed some programs intended to cover the whole South. The one example is Long's "drop-a-crop" program that would have suspended cotton planting for a whole year. The idea, whose inspiration came from Chapter 25 of Leviticus, was to aid farmers by inducing a reduction in supply that would increase prices so much that revenue would actually increase. Though South Carolina passed such a bill, it failed when Texas, a major producer of cotton, refused to join the 
scheme. If these policy proposals had uncertainty effects on surrounding states, in particular Mississippi, then this would tend to bias the estimated effects of uncertainty towards zero. ${ }^{7}$

Second, there is the perennial question of the quality of the control group. Is Mississippi in the 1930s really the counterfactual for Louisiana without Huey Long? One approach to address this is to consider an even more narrow set of treatment and control establishments by focusing only on the border counties of Louisiana and Mississippi. While the main specification controls for potential seasonal differences across the states due to differences in temperature or planting cycles between the state, one may still worry about different seasonal patterns at the sub-state level. By focusing on border counties, we eliminate any unobserved locational fixed effects or trends by assuming that the underlying physical fundamentals are "smooth" at the border while state policy is, by definition, discontinuous (Holmes 1998). While focusing on border counties addresses how representative the control group is, it may exacerbate the overestimation of aggregate effects with establishments in Louisiana right on the border most likely to migrate just across the border.

Third, there is the issue of how to disentangle movements in expected policy (first moment shocks) from changes in the distribution of policy (second moment shocks). There is a tendency to conflate increases in political uncertainty as related to a general decline in "confidence" not necessarily related to some objective change in the probabilities of various outcomes. Both the "mean" and "spread" interpretations posit effects going in the same direction (though through different mechanisms). Still it is difficult to tell apart changes in the "mean" of political uncertainty from the "spread" in political uncertainty. Our uncertainty measures only really attempt to measure the spread. The background assumption is that changes in the mean are negatively correlated with changes in the spread. This implies that we will tend to overestimate the direct effect of the "spread."

Finally, there is a question of the mechanism by which uncertainty affects economic outcomes. The classic channel is through a "waitand-see" effect whereby firms postpone investment (Bernanke 1983) and consumers postpone large durable purchases (Bertola, Guiso, and Pistaferri 2005). This in turn drags down overall aggregate spending,

\footnotetext{
${ }^{7}$ Generally, when attempting to estimate macro effects using local variation, there is the potential for overstating the aggregate effect as some of the employment losses for Louisiana translate into employment gains for Mississippi. This is also a problem in estimating fiscal multipliers using local variation in government spending such as in Fishback and Kachanovskaya (2011) and Nakamura and Steinsson (2014). In these cases the concern would be that the estimated effect would be biased downward as some of the spending would "leak out" into other areas.
} 
output, and employment. We call this the indirect expenditure channel. Unfortunately, information on either of these expenditure categories is not available at the state-level for the frequency we are interested in. Instead we will use information on employment, which is available at the establishment-level for manufacturing. Changes in employment have many of the same features as investment to the extent that hiring and firing are costly. Businesses uncertain about future profitability may slow the rate of hiring today or increase the firing rate in the face of an uncertainty shock, which will reduce the level of employment. This view of employment as a state variable which is costly to adjust is common to the literature, e.g. Bloom (2009) and Baker, Bloom, and Davis (2015). We would argue that even if employment were perfectly flexible, it would still be possible to observe a decline in employment in response to uncertainty shocks through the indirect expenditure channel. However, if this were the main route, it would be much more difficult to identify effects using the local variation we exploit since we expect that most investment demand by Louisiana establishments is for goods made by non-Louisiana establishments. We will address this possible difficulty by focusing on establishments that are dependent on local demand.

\section{MAIN RESULTS}

The baseline results are reported in Table 2. In the top panel, we use stock price volatility as our measure of uncertainty. We include a control for the average return to isolate the effects of changes in second moments. In the first three columns, we use the level of employment as the dependent variable and next three columns take the dependent variable as the first difference of log employment. The various specifications experiment with different numbers of lags of the mean return and volatility. Note that for the specification in first differences, we drop any plants who close and have employment fall to zero. The bottom panels of Table 2 are the results for two newspaper indexes as reported in Figure 3 that we created based on different key words: (1) "economic uncertainty" and (2) "commercial uncertainty." We have also tried another measure that had terms more closely related to Huey Long with very little difference in the results. For ease of interpretation, we center and scale each uncertainty measure so that each has a mean of 0 and a standard deviation of 1 .

We find little evidence for the effects of political uncertainty on employment outcomes. Using the stock measure, not only are the point estimates close to zero, the standard errors are also relatively small suggesting a one unit change (which is equal to one standard deviation) has at most a few percentage point effects in either direction. This is true 
TABLE 2

EFFECTS OF UNCERTAINTY USING THE FULL SAMPLE OF PLANTS IN LOUISIANA AND MISSISSIPPI

\begin{tabular}{|c|c|c|c|c|c|c|}
\hline & \multicolumn{3}{|c|}{ Log Wage Earners } & \multicolumn{3}{|c|}{ Log Change in Wage Earners } \\
\hline & (1) & (2) & (3) & (4) & (5) & (6) \\
\hline \multicolumn{7}{|c|}{ A: Stock Return Volatility Measure } \\
\hline Mean return & $\begin{array}{l}9.564^{*} \\
(5.398)\end{array}$ & $\begin{array}{c}11.41 \\
(6.948)\end{array}$ & $\begin{array}{c}34.66 * * * \\
(7.396)\end{array}$ & $\begin{array}{l}-0.896 \\
(0.911)\end{array}$ & $\begin{array}{l}-0.867 \\
(0.749)\end{array}$ & $\begin{array}{c}0.365 \\
(0.859)\end{array}$ \\
\hline Volatility & $\begin{array}{c}0.0110 \\
(0.0139)\end{array}$ & $\begin{array}{c}0.0140 \\
(0.0165)\end{array}$ & $\begin{array}{l}0.00705 \\
(0.0176)\end{array}$ & $\begin{array}{l}-0.00137 \\
(0.00190)\end{array}$ & $\begin{array}{l}-0.00047 \\
(0.00163)\end{array}$ & $\begin{array}{c}-0.00556^{* * *} * \\
(0.00107)\end{array}$ \\
\hline Lag mean return & & $\begin{array}{c}7.178 \\
(4.628)\end{array}$ & $\begin{array}{c}6.185 \\
(6.954)\end{array}$ & & $\begin{array}{l}-0.161 \\
(0.591)\end{array}$ & $\begin{array}{l}0.809^{*} \\
(0.457)\end{array}$ \\
\hline Lag volatility & & $\begin{array}{c}0.0172 \\
(0.0144)\end{array}$ & $\begin{array}{c}0.0207 \\
(0.0181)\end{array}$ & & $\begin{array}{l}-0.00115 \\
(0.00159)\end{array}$ & $\begin{array}{c}-0.00316^{* *} \\
(0.00127)\end{array}$ \\
\hline 2nd lag mean return & & & $\begin{array}{l}12.17 * \\
(6.638)\end{array}$ & & & $\begin{array}{l}-0.879 \\
(0.600)\end{array}$ \\
\hline 2nd lag volatility & & & $\begin{array}{c}0.0563^{* * *} * \\
(0.0176) \\
\end{array}$ & & & $\begin{array}{l}-0.00191 \\
(0.00178) \\
\end{array}$ \\
\hline Observations & 72,187 & 66,023 & 59,843 & 65,306 & 65,306 & 59,177 \\
\hline Adjusted $R^{2}$ & 0.437 & 0.436 & 0.435 & 0.011 & 0.011 & 0.016 \\
\hline \multicolumn{7}{|c|}{ B: "Economic" Newspaper Measure } \\
\hline Economic measure & $\begin{array}{c}0.0321 * * * \\
(0.0116)\end{array}$ & $\begin{array}{c}0.0240 * * \\
(0.0112)\end{array}$ & $\begin{array}{l}0.0214 * \\
(0.0117)\end{array}$ & $\begin{array}{c}-0.00370^{* *} \\
(0.00149)\end{array}$ & $\begin{array}{c}-0.00292 * \\
(0.00146)\end{array}$ & $\begin{array}{c}-0.00406^{* * * *} \\
(0.00115)\end{array}$ \\
\hline Lag economic measure & & $\begin{array}{c}0.0298^{* *} \\
(0.0145)\end{array}$ & $\begin{array}{c}0.0217 \\
(0.0141)\end{array}$ & & $\begin{array}{c}-0.00289^{*} \\
(0.00148)\end{array}$ & $\begin{array}{l}-0.00231 \\
(0.00165)\end{array}$ \\
\hline 2nd lag economic measure & & & $\begin{array}{c}0.0277^{* *} \\
(0.0134)\end{array}$ & & & $\begin{array}{l}0.000327 \\
(0.00127)\end{array}$ \\
\hline Observations & 75,443 & 69,279 & 63,099 & 68,522 & 68,522 & 62,393 \\
\hline Adjusted $R^{2}$ & 0.439 & 0.438 & 0.437 & 0.014 & 0.014 & 0.019 \\
\hline \multicolumn{7}{|c|}{ C: "Commerce" Newspaper Measure } \\
\hline Commerce measure & $\begin{array}{c}-0.0373 * * * \\
(0.0117)\end{array}$ & $\begin{array}{l}-0.0213 \\
(0.0134)\end{array}$ & $\begin{array}{l}-0.0207 \\
(0.0149)\end{array}$ & $\begin{array}{c}0.00296 \\
(0.00181)\end{array}$ & $\begin{array}{l}0.00359 * \\
(0.00211)\end{array}$ & $\begin{array}{c}0.00359 \\
(0.00230)\end{array}$ \\
\hline Lag commerce measure & & $\begin{array}{c}-0.0307^{* *} \\
(0.0140)\end{array}$ & $\begin{array}{l}-0.0176 \\
(0.0138)\end{array}$ & & $\begin{array}{l}-0.00137 \\
(0.00185)\end{array}$ & $\begin{array}{c}-0.000146 \\
(0.00196)\end{array}$ \\
\hline 2nd Lag Commerce Measure & & & $\begin{array}{l}-0.0238 \\
(0.0145) \\
\end{array}$ & & & $\begin{array}{l}-0.00218 \\
(0.00167) \\
\end{array}$ \\
\hline Observations & 75,443 & 69,279 & 63,099 & 68,522 & 68,522 & 62,393 \\
\hline Adjusted $R^{2}$ & 0.439 & 0.438 & 0.437 & 0.014 & 0.014 & 0.019 \\
\hline
\end{tabular}

Standard errors in parentheses.

$* p<0.10, * * p<0.05, * * * p<0.01$

Notes: Panel A uses the stock volatility measure controlling for mean returns. Panel B uses our newspaper index searching for keywords related to "economic." Panel C uses the newspaper index searching for keywords related to "commerce." Standard errors are clustered at the year-month level. All of the uncertainty measures have been demeaned and scaled to result in a series with a standard deviation of 1 . So the coefficients for the uncertainty effect are comparable across uncertainty measures. All regressions include industry and year fixed effects as well as state specific seasonal trends. An observation is a month-year-establishment value.

Sources: New Orleans Times Picayune, Census of Manufactures (Department of Commerce). 
in the levels specification as well as in the first differences specification. When we turn to the newspaper measures in the bottom two panels, we again find limited effects. There are some negative effects of the commerce measure, but this is at odds with the positive measured effect of the economic newspaper index. Furthermore, if we turn to the effects on changes in log employment, there are small effects that are precisely estimated. Somewhat oddly, the positive effects of the economic index are persistent over time with both the first and second lags entering positively.

We now restrict attention to the set of counties that make up the border of Louisiana and Mississippi. ${ }^{8}$ Results are reported in Table 3, where we report the same set of specifications as the baseline results. The panel estimations follow the baseline specifications with the different measures of uncertainty. Even after restricting attention to the border counties, effects are still statistically indistinguishable from zero with larger standard errors due to the smaller sample size. The commerce measure does enter negatively but this is not very robust to the number of lags. Furthermore, when we use the change in employment, the commerce measure of uncertainty is positively correlated with employment growth, which casts doubt on the negative effects of uncertainty in the first place.

These results are entirely consistent with the overall patterns of statelevel income and employment for Louisiana relative to Mississippi or other bordering states. Figure 5 plots estimates of per capita income where we normalize income levels in 1929 to 100. If anything, Louisiana appears to do slightly better during the downturn when Long held political control and the (minor) gap is only closed after Long's assassination. This pattern is essentially unchanged when we consider the statelevel employment estimates from John Joseph Wallis (1989) reported in Figure 6 as Louisiana and surrounding states performed similarly.

We also consider the effect of Long on oil production in his state, as no company was more of a target for Huey's invective and regulatory and tax changes than Standard Oil of Louisiana. Shreveport, where the company was based, was a bastion of anti-Long sentiment, though other parts of the oil industry were equally hostile to Long. Using data on oil production in states and in the nation as a whole, we compare Louisiana's oil production to a neighboring state with a large oil industry, Texas, and

8 These include the following counties for Mississippi: Issaquena, Warren, Claiborne, Jefferson, Adams, Wilkinson, Amite, Pike, Walthall, Marion, Pearl River, and Hancock. For Louisiana, these are the parishes of East Carroll, Madison, Tensas, Concordia, West Feliciana, East Feliciana, St. Helena, Tangipahoa, Washington, and St. Tammany. 
TABLE 3

EFFECTS OF UNCERTAINTY RESTRICTING ATTENTION TO PLANTS IN COUNTIES ON THE BORDER OF LOUISIANA AND MISSISSIPPI

\begin{tabular}{|c|c|c|c|c|c|c|}
\hline & \multicolumn{3}{|c|}{ Log Wage Earners } & \multicolumn{3}{|c|}{ Log Change in Wage Earners } \\
\hline & (1) & (2) & (3) & (4) & (5) & (6) \\
\hline \multicolumn{7}{|c|}{ A: Stock Return Volatility Measure } \\
\hline Mean & $\begin{array}{c}23.22 \\
(16.98)\end{array}$ & $\begin{array}{c}28.50 \\
(20.70)\end{array}$ & $\begin{array}{c}81.72 * * * \\
(17.05)\end{array}$ & $\begin{array}{c}3.659 \\
(3.059)\end{array}$ & $\begin{array}{c}4.768 \\
(3.517)\end{array}$ & $\begin{array}{c}0.796 \\
(4.198)\end{array}$ \\
\hline Volatility & $\begin{array}{c}0.0225 \\
(0.0468)\end{array}$ & $\begin{array}{c}0.0383 \\
(0.0542)\end{array}$ & $\begin{array}{c}0.0179 \\
(0.0498)\end{array}$ & $\begin{array}{l}-0.00466 \\
(0.00887)\end{array}$ & $\begin{array}{l}-0.00239 \\
(0.00885)\end{array}$ & $\begin{array}{c}0.00873 \\
(0.00960)\end{array}$ \\
\hline Lag mean & & $\begin{array}{c}17.32 \\
(15.49)\end{array}$ & $\begin{array}{c}10.21 \\
(20.56)\end{array}$ & & $\begin{array}{c}1.218 \\
(2.636)\end{array}$ & $\begin{array}{c}2.592 \\
(2.188)\end{array}$ \\
\hline Lag volatility & & $\begin{array}{c}0.0474 \\
(0.0464)\end{array}$ & $\begin{array}{c}0.0705 \\
(0.0547)\end{array}$ & & $\begin{array}{c}-0.0187 * \\
(0.00976)\end{array}$ & $\begin{array}{c}-0.0115 \\
(0.00771)\end{array}$ \\
\hline 2nd lag mean & & & $\begin{array}{l}34.81^{*} \\
(18.45)\end{array}$ & & & $\begin{array}{c}9.338 * * * \\
(3.292)\end{array}$ \\
\hline 2nd lag volatility & & & $\begin{array}{l}0.114 * * \\
(0.0484) \\
\end{array}$ & & & $\begin{array}{l}-0.0183 * \\
(0.00956) \\
\end{array}$ \\
\hline Observations & 4,530 & 4,148 & 3,766 & 4,088 & 4,088 & 3,710 \\
\hline Adjusted $R^{2}$ & 0.587 & 0.585 & 0.584 & 0.008 & 0.009 & 0.011 \\
\hline \multicolumn{7}{|c|}{ B: “Economic” Newspaper Measure } \\
\hline Economic measure & $\begin{array}{c}0.113 * * * \\
(0.0294)\end{array}$ & $\begin{array}{c}0.0821 * * * \\
(0.0300)\end{array}$ & $\begin{array}{c}0.0670 * * \\
(0.0315)\end{array}$ & $\begin{array}{c}-0.0163 * * \\
(0.00658)\end{array}$ & $\begin{array}{l}-0.0134 * \\
(0.00745)\end{array}$ & $\begin{array}{c}-0.0112 \\
(0.00826)\end{array}$ \\
\hline Lag economic measure & & $\begin{array}{c}0.0953 * * \\
(0.0417)\end{array}$ & $\begin{array}{c}0.0672 \\
(0.0414)\end{array}$ & & $\begin{array}{l}-0.00874 \\
(0.00845)\end{array}$ & $\begin{array}{c}-0.0148 \\
(0.00896)\end{array}$ \\
\hline 2nd lag economic measure & & & $\begin{array}{c}0.0891 * * \\
(0.0391) \\
\end{array}$ & & & $\begin{array}{c}0.0127 \\
(0.00803) \\
\end{array}$ \\
\hline Observations & 4,671 & 4,289 & 3,907 & 4,229 & 4,229 & 3,851 \\
\hline Adjusted $R^{2}$ & 0.597 & 0.596 & 0.595 & 0.010 & 0.010 & 0.010 \\
\hline \multicolumn{7}{|c|}{ C: “Commerce” Newspaper Measure } \\
\hline Commerce measure & $\begin{array}{c}-0.136^{* * *} \\
(0.0294)\end{array}$ & $\begin{array}{c}-0.0717 * \\
(0.0359)\end{array}$ & $\begin{array}{l}-0.0597 \\
(0.0388)\end{array}$ & $\begin{array}{c}0.0134 \\
(0.00932)\end{array}$ & $\begin{array}{c}0.0193 * \\
(0.00979)\end{array}$ & $\begin{array}{l}0.0224 * \\
(0.0125)\end{array}$ \\
\hline Lag commerce measure & & $\begin{array}{c}-0.109 * * * \\
(0.0385)\end{array}$ & $\begin{array}{l}-0.0627 \\
(0.0384)\end{array}$ & & $\begin{array}{c}-0.0118 \\
(0.00867)\end{array}$ & $\begin{array}{l}-0.00971 \\
(0.00931)\end{array}$ \\
\hline 2nd lag commerce measure & & & $\begin{array}{c}-0.0869^{* *} \\
(0.0409) \\
\end{array}$ & & & $\begin{array}{c}-0.00902 \\
(0.0102) \\
\end{array}$ \\
\hline Observations & 4,671 & 4,289 & 3,907 & 4,229 & 4,229 & 3,851 \\
\hline Adjusted $R^{2}$ & 0.597 & 0.596 & 0.595 & 0.009 & 0.009 & 0.009 \\
\hline
\end{tabular}

Standard errors in parentheses.

$* p<0.10, * * p<0.05, * * * p<0.01$

Notes: Panel A uses the stock volatility measure controlling for mean returns. Panel B uses our newspaper index based on "economic" terms. Panel C uses the newspaper index based on "commercial" terms. Standard errors are clustered at the year-month level. All of the uncertainty measures have been demeaned and scaled to result in a series with a standard deviation of 1 . So the coefficients for the uncertainty effect are comparable across uncertainty measures. All regressions include industry and year fixed effects as well as state specific seasonal trends. An observation is a month-year-establishment value.

Source: New Orleans Times Picayune, Census of Manufactures (Department of Commerce). 


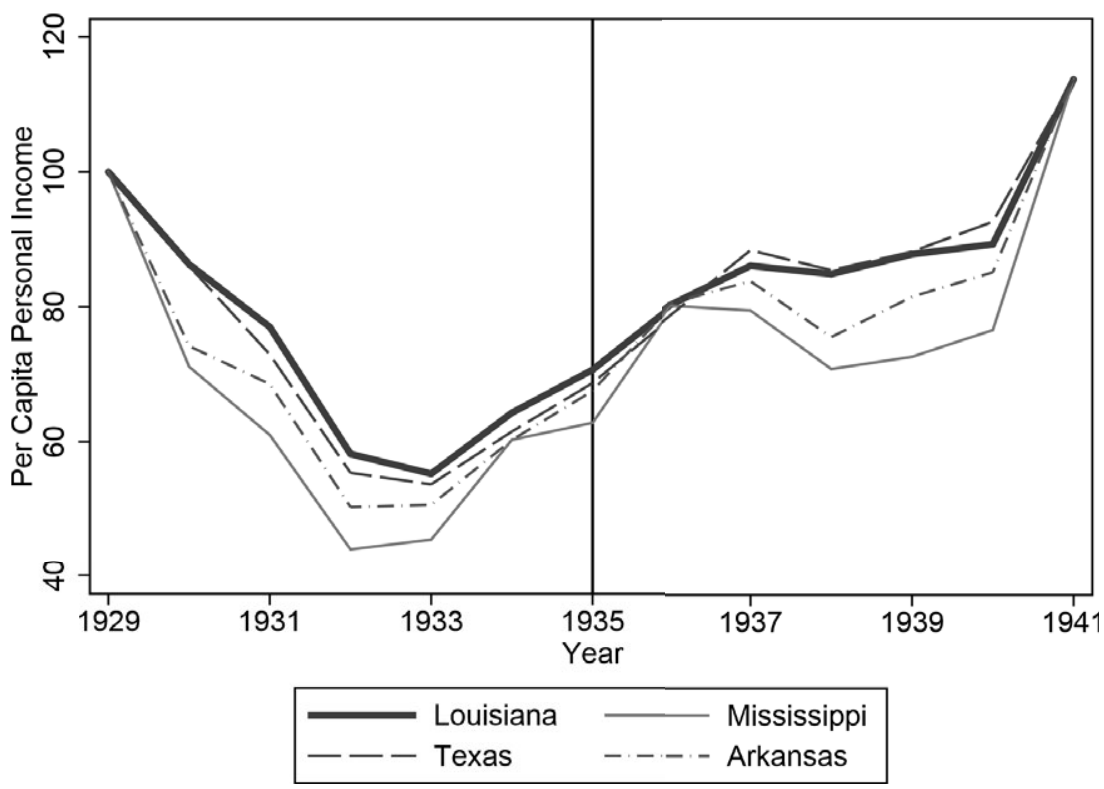

FIGURE 5

PERSONAL INCOME PER CAPITA IN LOUISIANA AND NEIGHBORING STATES TO 1929 VALUES AS 100. BLACK LINE REFERS TO THE LONG ASSASSINATION YEAR

Source: Bureau of Economic Analysis.

with the nation's oil production as a whole. As can be seen in Figure 7, Louisiana's oil production relative to Texas stabilized after declining prior to Huey's 1928 election as governor. However, recall that Long was on the Public Service Commission starting in 1918 so there may have been an effect prior to his becoming the governor. Louisiana's oil production grew at a similar rate through about 1933 and then started to outpace Texas after Long's demise. This would be consistent with an uncertainty effect stemming from Long's policies, though there is not much of a break in the trend. At the same time, Texas also had a string of discoveries in the early 1930s that would swell Texas's proven oil reserves to be 56 percent of the nation's by 1940 (Libecap 1989, p. 836). So it is difficult to attribute any differential growth rates solely to Long. Turning to the national comparison, Louisiana oil production grew in line with United States oil production from 1926 to 1933, before rising through 1938. The growth of U.S. production over Louisiana production accelerates somewhat after the 1935 assassination though growth slows after 1936. While clearly not overwhelming, this is perhaps the strongest evidence for effects of political uncertainty generated by Long. 


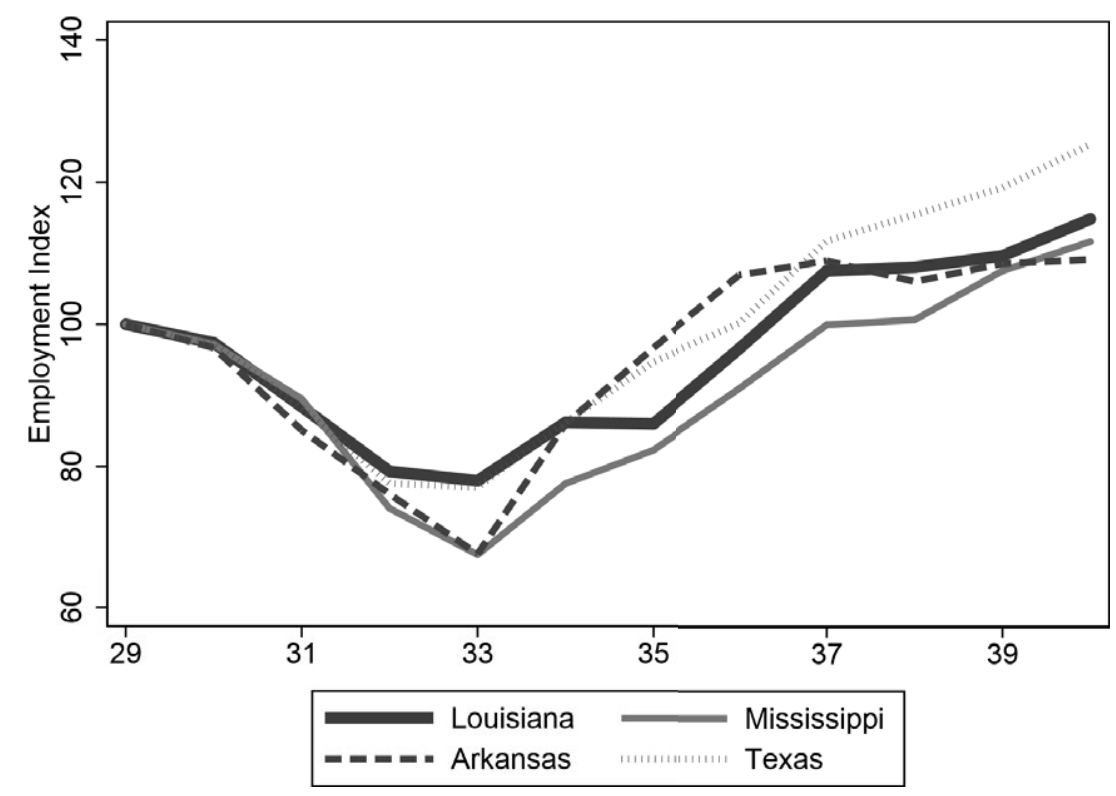

FIGURE 6

NON-AGRICULTURAL EMPLOYMENT INDEXES NORMALIZED TO 1929 VALUES

FOR LOUISIANA AND SURROUNDING STATES

Source: Wallis (1989).

\section{EVENT STUDY ANALYSIS OF RETURNS OF LOUISIANA STOCKS ON THE NYSE}

We use information on the several Louisiana companies that were listed on the NYSE during this period. Using data from the Center for Research in Security Prices (CRSP), we focus on the Louisiana Oil Refining Corporation (LORC), which has stock return data through 1935. By virtue of being both an oil company (and thus a prime target of Long) as well as being located in Louisiana (and thus affected by Long's policies), any effect from political uncertainty resulting from Long policies should be observable in LORC's stock behavior. Second, we consider Standard Oil of New Jersey (SONJ), which was the branch of Standard Oil active in Louisiana, that was also listed on the NYSE. Finally, Penick and Ford was a manufacturer of sweet syrups and molasses, famous for Brer Rabbit Molasses, which operated mainly in Louisiana.

Before conducting the event study, Panel (c) of Figure 2 shows the volatility of these three Louisiana-sensitive stocks divided by the stock volatility of the overall S\&P500 index. ${ }^{9}$ Volatility for these stocks is

\footnotetext{
${ }^{9}$ The S\&P 500 did not exist at the time, but CRSP constructs a similar index using the S\&P 500 methodology.
} 


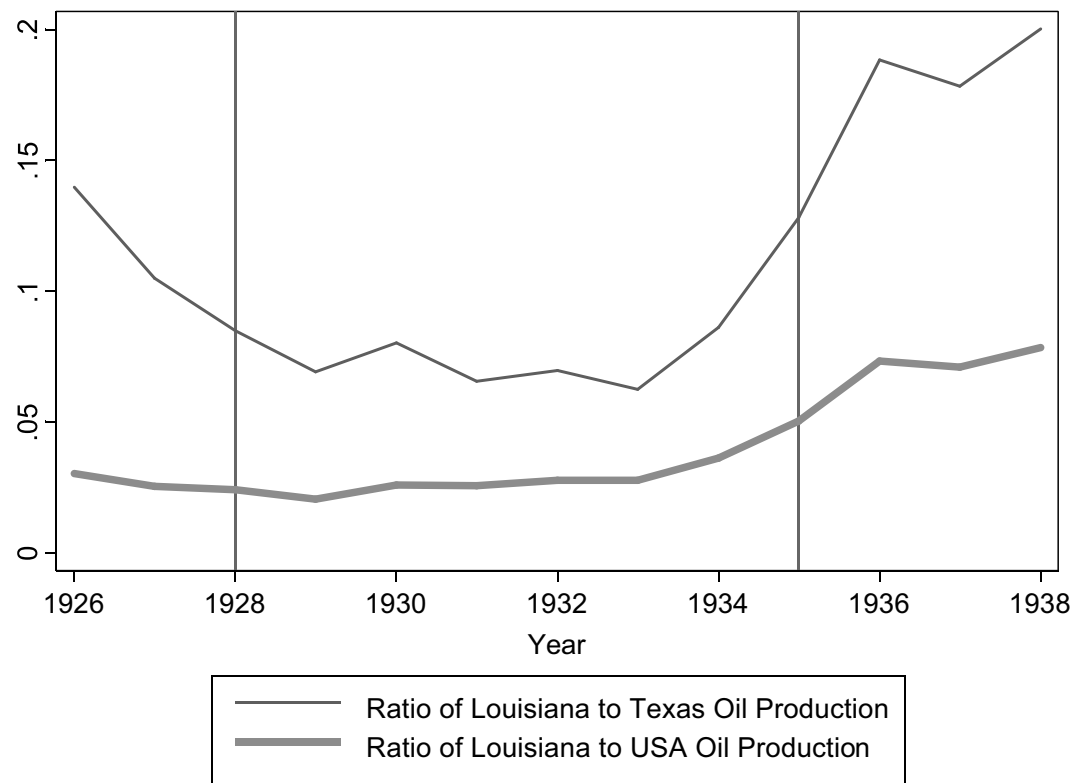

FIGURE 7

RATIO OF LOUISIANA OIL PRODUCTION TO TEXAS AND U.S. OIL PRODUCTION BASED ON FIGURES

Source: Department of Commerce's Bureau of Mines Minerals Yearbook, published in U.S. Statistical Yearbook, various years.

generally the same or lower than for the aggregate stock market, while if Long's policies really generated uncertainty for these corporations, their stock prices should have been more volatile. Also, the events do not seem to drive up volatility for these Louisiana-sensitive stocks relative to the overall stock market. This is consistent with our earlier results for stocks on the NOSE.

For the event study, we run a regression of the ex dividend return on the stock $i$ at date $t, r_{i t}$ relative to the return on the Standard and Poor's $500 r_{t}$, as well as indicator variables $d_{j t}$ for the events $j=1 \ldots J$. Here $\alpha_{i}$ $+\beta_{i} r_{i t}$ captures the predicted individual stock return while the indicator variables capture the additional excess return for each of these events.

$$
r_{i t}=\alpha_{i}+\beta_{i} r_{t}+\sum_{j=1}^{J} \gamma_{j} d_{j t}+\varepsilon_{i t} .
$$

Table 4 shows the regression results. ${ }^{10}$ For some of the events, such as Long's assassination, we might expect positive excess returns on the

${ }^{10}$ Standard errors on the event indicators are not well defined since they are based on a single stock return, so they are not listed. 
TABLE 4

EVENT STUDIES OF EXCESS STOCK RETURNS FOR LOUISIANA-BASED STOCKS LISTED ON THE NYSE

\begin{tabular}{lccc}
\hline \hline & \multicolumn{2}{c}{ Return on stock of ... } & \\
\cline { 2 - 3 } & $\begin{array}{c}\text { Penick and Ford } \\
(1)\end{array}$ & $\begin{array}{c}\text { Louisiana Refining } \\
\text { Corp. } \\
(2)\end{array}$ & $\begin{array}{c}\text { Standard Oil } \\
\text { of NJ } \\
(3)\end{array}$ \\
\hline S\&P 500 return & $0.696^{* * *}$ & $1.029^{* * *}$ & $0.812^{* * *}$ \\
Event & $(0.0206)$ & $(0.0907)$ & $(0.0102)$ \\
Huey Elected Governor & & & \\
Huey Announces Oil Severance Tax & -0.0142 & -0.00510 & 0.00202 \\
Bloody Monday & -0.0161 & 0.0202 & -0.0173 \\
Long Impeachment & 0.0341 & -0.0120 & -0.0179 \\
Lt. Gov. Cyr to become governor & -0.0130 & -0.0205 & -0.00228 \\
Square Deal Crisis & 0.00274 & - & 0.0123 \\
Long assassination & - & - & 0.000233 \\
\hline Observations & 0.00723 & 0.000835 & -0.00316 \\
Adjusted $R^{2}$ & 3,557 & 2,242 & 4,776 \\
\hline Standart & 0.243 & 0.052 & 0.572 \\
\hline
\end{tabular}

Standard errors in parentheses.

$* p<0.10, * * p<0.05, * * * p<0.01$

Notes: Estimated coefficients for date indicator variables are the excess return for the Hueyrelated events listed. We do not report standard errors as these estimated event effects are based on a single observation, though none are statistically significant. Dashes correspond to dates without return data.

Source: Center for Research in Security Prices (CRSP), accessed by Wharton Research Data Services (WRDS).

day the information is revealed, while for the announcement of the tax targeting Standard Oil in 1929, one could expect a negative excess return. However, after controlling for the overall return on the S\&P 500, the excess returns on these stocks are quite small. Perhaps there is some evidence that the returns of a company like the Louisiana Oil Refining Corporation which was a prime Long target were affected by some of the events.

\section{OTHER INTERPRETATIONS OF THE NULL EFFECT}

There are a number of other interpretations of these null results beyond our preferred one that political uncertainty simply did not matter. One is that perhaps Long did not generate that much uncertainty, relative to the national average or the control group of Mississippi. Second, one might argue that Long was not really that extreme when compared to other governors at the time. Third, Long also enacted policies that ostensibly would have had positive effects on growth such as the major road 
building that took place. Fourth, it might be that uncertainty matters but that the effects are not localized and mainly affect supplies of investment goods to Louisiana producers. It is also possible that the unchecked power of the Long machine eliminated political gridlock which reduced policy uncertainty to some extent. Political gridlock is a primary driver of policy uncertainty as shown by Baker, Bloom, and Davis (2015). Concretely, this interpretation would imply a large negative effect when Long is assassinated and normal democratic processes resume. Compare this to the more standard interpretation where Long's assassination would imply a positive effect with the resolution of uncertainty.

We now conduct an event study of Long's assassination to address these possible interpretations. Besides addressing this concern, there are two additional reasons for considering this event study. First, even in our treatment-control setup, there is still a question if whether the relative increases in political uncertainty during Huey's tenure are due to economic events particular to Louisiana. Similar to the work by Benjamin F. Jones and Benjamin A. Olken (2005) and Baker, Carola Frydman, and Eric Hilt (2014), Long's assassination is useful as an arguably exogenous and unforeseen event that put an end to his political dominance of Louisiana. The second reason for studying this event is that based on narrative evidence, it did appear to have affected people's beliefs about the direction of policy. For example, the yield on New Orleans' 30 -year bonds, for example, fell from 4.40 percent to 3.85 percent, and the price of Louisiana highway bonds maturing in 1955 rose from 102 to 113.5 between mid-September and mid-December 1935 (Wall Street Journal, 16 December 1935, p. 15). The Wall Street Journal explained these changes, "Senator Long's death apparently has restored confidence of the more timid investors in the state's credit and that confidence is reflected in the prices paid for the state's obligations." Other observers at the time seemed to agree with our analysis. For example, the New York Times (11 September 1935, p. 31), quoting from an article in The Sun (Ind. Rep.), wrote, "There were those in bond circles yesterday who watched carefully the market for State of Louisiana bonds in expectation that the death of Senator Huey Long might exert some influence on those issues marketwise."

We estimate similar specifications as before, but now rather than the uncertainty measures as our key explanatory variables, we have an indicator variable for pre-assassination period. This will be equal to 1 if establishment $i$ is in Louisiana and the month is prior to September 1935. There is a question about whether we should treat the month of September as pre- or post-treatment since Long's assassination takes place in the middle of the month (September 10). The Census asked plants to report 
TABLE 5

EFFECT OF ASSASSINATION OF HUEY LONG ON EMPLOYMENT

\begin{tabular}{lcccccc}
\hline \hline & \multicolumn{6}{c}{ Log Wage Earners } \\
\cline { 2 - 7 } & $(1)$ & $(2)$ & $(3)$ & $(4)$ & $(5)$ & $(6)$ \\
\hline Before assassination & 0.00255 & -0.00798 & -0.000553 & -0.00504 & 0.00963 & -0.0450 \\
& $(0.0231)$ & $(0.0231)$ & $(0.0248)$ & $(0.0562)$ & $(0.0534)$ & $(0.0650)$ \\
\hline Sept. 1935? & Pre & Post & Exclude & Pre & Post & Exclude \\
Sample? & All & All & All & Border & Border & Border \\
\hline
\end{tabular}

Standard errors in parentheses.

$* p<0.10, * * p<0.05, * * * p<0.01$

Notes: These regressions use only data for the year of 1935. The row "Sept. 1935?" reports how we treated observations from the month of Long's assassination. Standard errors are clustered at the month-level. An observation is a month-year-establishment value. All regressions include industry and state fixed effects.

Source: Census of Manufactures (Department of Commerce).

employment counts for the week that included the 15th of the month, precisely the week that Long was assassinated. This leads us to consider two ways to proceed: (1) treat September as part of the post-Long period and (2) exclude September observations. Note that like the earlier regressions, we will only be looking at short-term effects as we have only at most three months of observations (October, November, and December) post Long's assassination.

Table 5 reports the regression results across various specifications for what is considered the post-Long period. These various choices appear to make little difference. Column 1 reports the baseline effect with an estimate close to zero, though imprecisely estimated. A 95 percent confidence interval includes a positive or negative 4 percent impact on Louisiana employment of Long's assassination. Given the narrative evidence and financial market response, it is perhaps surprising that we are unable to detect a positive effect of Long's death though it is consistent with our earlier results. Columns 2 and 3 use the other coding schemes for the Huey Long variable. These specifications display limited effects as well. We also estimate the same regression using only those establishments near the Mississippi-Louisiana border, an arguably more convincing identification of the impact of Long's rule. The last three columns of Table 5 report these results for the three codings for Long's assassination variable. The results are unchanged and stable across specifications. As before, 95 percent confidence intervals include very large positive or negative impacts of Long's death.

Second, other governors at the time were outspoken populists including Mississippi which was governed by Theodore Bilbo. So it is possible that Long was just not that unique or particularly extreme. 
We would argue just the opposite. There is good reason to view Huey Long's Louisiana as a special and extreme case characterized by more absolute control and a more arbitrary decision making process, which meant that businessmen had little sense of what the future held and little recourse against the caprices of the Louisiana government. Bilbo was a progressive and populist like Long, who characterized his program of infrastructure and education as "bricks and books." However, Bilbo was effectively blocked by the conservative Mississippi legislature and failed to win re-election in 1932 after an ineffective term as governor (Brinkley 1983, pp. 218-19). The contrast could not be more stark, with Long's total control of Louisiana celebrated by his supporters and decried by his opponents. A similar case can be seen in Eugene Talmadge of Georgia, another popular Southern governor. While the Talmadge administration did manage to lower state licensing fees, property taxes, and railroad and utility rates, this was combined with sharp budget cuts, sizable reductions in state services, a militant aversion to labor unions, and a friendly relationship with business interests in the state. This makes for a stark contrast with the Long program (Brinkley 1983, pp. 216-17).

Third, it is possible that our null result stems from two offsetting effects: a negative effect of political uncertainty and a positive effect stemming from increased infrastructure spending. At the height of Long's public works program, more construction workers were employed in Louisiana than in any other state, and about one-tenth of all construction workers in the country were employed in Louisiana (Williams 1981, p. 547). Free schoolbooks were provided to children at both public and private schools (Williams 1981, p. 308), and Long funded his beloved Louisiana State University extensively. While this type of offset cannot be ruled out, this would imply that the magnitude of the negative effect of political uncertainty should be roughly match by the positive effects of Long's policies. Moreover, even if these effects were to offset over a period of several months or years, we should still see positive and negative changes in equity markets on days when information about negative or positive aspects of Long's program are revealed, but we do not find evidence of this either.

Finally, many Mississippi plants may have their main customers in Louisiana and vice versa. If the effect of uncertainty works through dampening demand be it investment or consumer, then the effects of uncertainty may not be localized to Louisiana businesses but spillover to Mississippi businesses with consumers in Louisiana. One way to address this concern is to examine how the estimated uncertainty effects vary depending on the degree of tradeability of an industry's output. It is difficult to develop 
TABLE 6

EFFECTS OF UNCERTAINTY RESTRICTING ATTENTION TO PLANTS IN THE MANUFACTURED ICE INDUSTRY, A NON-TRADEABLE PRODUCT

\begin{tabular}{|c|c|c|c|c|c|c|}
\hline & \multicolumn{3}{|c|}{ Log Wage Earners } & \multicolumn{3}{|c|}{ Log Change in Wage Earners } \\
\hline & (1) & (2) & (3) & (4) & (5) & (6) \\
\hline Stock Volatility & $\begin{array}{l}0.00345 \\
(0.0206)\end{array}$ & & & $\begin{array}{l}-0.00660 \\
(0.00904)\end{array}$ & & \\
\hline Economic Newspaper & & $\begin{array}{c}0.0480^{* * * *} \\
(0.0117)\end{array}$ & & & $\begin{array}{l}-0.00568 \\
(0.00603)\end{array}$ & \\
\hline Commerce Newspaper & & & $\begin{array}{c}-0.0403 * * * \\
(0.0131)\end{array}$ & & & $\begin{array}{c}0.0117 \\
(0.00890)\end{array}$ \\
\hline
\end{tabular}

Standard errors in parentheses.

$* p<0.10, * * p<0.05, * * * p<0.01$

Notes: For each uncertainty measure, we estimate the contemporaneous effect. All of the uncertainty measures have been demeaned and scaled to result in a series with a standard deviation of 1 . So the coefficients for the uncertainty effect are comparable across uncertainty measures. All regressions include year fixed effects and state specific seasonal trends. An observation is a month-year-establishment value.

Sources: Census of Manufactures (Department of Commerce), New Orleans Times Picayune.

a general measure of tradeability for the various manufactured products without information on shipments. Instead we will study one industry, manufactured ice, for which demand is quite localized.

Table 6 reports the regressions for establishments in the ice industry. For the sake of brevity, we only report the contemporaneous correlations. Including more lags as in the previous specifications did not change the results, and the results for this test are entirely consistent with those of the full sample. There is no consistent pattern across the estimate suggesting a strong negative effect of uncertainty in the first three columns using the level of wage earners. The other three specifications using the log change shows insignificant effects. We conclude from these results that the overall null effect is not due to spillovers in demand leading to declines in employment in both states.

\section{DID SOME ESTABLISHMENTS BENEFIT FROM LONG?}

We now consider whether the effects of uncertainty differed by plant sizes. Theory does not provide a clear prediction for the heterogeneity in the effect of uncertainty between plants of differing sizes. If employment adjustment costs are increasing in establishment size, then we would expect larger negative effects for the largest establishments. Furthermore, the narrative evidence suggests that, if anything, Long's policies and rhetoric were aimed at the largest plants. On this basis we would expect 
TABLE 7

EFFECTS OF UNCERTAINTY ACROSS QUANTILES OF PLANT SIZE AS MEASURED BY EMPLOYMENT IN JANUARY OF GIVEN YEAR

\begin{tabular}{|c|c|c|c|c|c|c|c|c|}
\hline \multirow{2}{*}{$\begin{array}{l}\text { Employment } \\
\text { Size Quartile }\end{array}$} & \multicolumn{4}{|c|}{ Log Wage Earners } & \multicolumn{4}{|c|}{ Log Change in Wage Earners } \\
\hline & Bottom & Second & Third & Top & Bottom & Second & Third & Top \\
\hline \multicolumn{9}{|c|}{ A: Stock Return Volatility Measure } \\
\hline Mean return & $\begin{array}{l}-1.369 \\
(1.868)\end{array}$ & $\begin{array}{l}-0.808 \\
(1.566)\end{array}$ & $\begin{array}{l}0.0692 \\
(0.783)\end{array}$ & $\begin{array}{l}-0.196 \\
(1.040)\end{array}$ & $\begin{array}{l}-0.505 \\
(1.774)\end{array}$ & $\begin{array}{l}-0.371 \\
(0.830)\end{array}$ & $\begin{array}{c}0.804 \\
(0.656)\end{array}$ & $\begin{array}{c}-0.0916 \\
(0.515)\end{array}$ \\
\hline Volatility & $\begin{array}{l}-0.00522 \\
(0.00757)\end{array}$ & $\begin{array}{l}-0.0104 * \\
(0.00610)\end{array}$ & $\begin{array}{l}-0.00338 \\
(0.00323)\end{array}$ & $\begin{array}{c}0.000863 \\
(0.00539)\end{array}$ & $\begin{array}{c}-0.000554 \\
(0.00455)\end{array}$ & $\begin{array}{l}0.000821 \\
(0.00427)\end{array}$ & $\begin{array}{c}-0.00628^{* *} \\
(0.00255)\end{array}$ & $\begin{array}{l}-0.00189 \\
(0.00192)\end{array}$ \\
\hline Observations & 19,250 & 14,596 & 13,941 & 14,378 & 17,166 & 13,200 & 12,661 & 13,191 \\
\hline Adjusted $R^{2}$ & 0.694 & 0.919 & 0.914 & 0.790 & 0.064 & 0.011 & 0.062 & 0.111 \\
\hline \multicolumn{9}{|c|}{ B: "Economic" Newspaper Measure } \\
\hline $\begin{array}{l}\text { Economic } \\
\text { measure }\end{array}$ & $\begin{array}{c}-0.000481 \\
(0.00706)\end{array}$ & $\begin{array}{l}-0.00498 \\
(0.00611)\end{array}$ & $\begin{array}{l}-0.00485 \\
(0.00380)\end{array}$ & $\begin{array}{c}0.0000659 \\
(0.00720)\end{array}$ & $\begin{array}{c}0.00164 \\
(0.00585)\end{array}$ & $\begin{array}{l}-0.00295 \\
(0.00309)\end{array}$ & $\begin{array}{l}-0.00507 \\
(0.00357)\end{array}$ & $\begin{array}{r}-0.000197 \\
(0.00346)\end{array}$ \\
\hline Observations & 19,294 & 14,652 & 13,974 & 14,436 & 17,210 & 13,254 & 12,694 & 13,249 \\
\hline Adjusted $R^{2}$ & 0.695 & 0.919 & 0.914 & 0.790 & 0.064 & 0.011 & 0.063 & 0.110 \\
\hline \multicolumn{9}{|c|}{ C: "Commerce” Newspaper Measure } \\
\hline $\begin{array}{r}\text { Commerce } \\
\text { measure }\end{array}$ & $\begin{array}{l}-0.00754 \\
(0.00519)\end{array}$ & $\begin{array}{l}-0.00900 \\
(0.00558)\end{array}$ & $\begin{array}{l}-0.00236 \\
(0.00371)\end{array}$ & $\begin{array}{c}0.0106^{*} \\
(0.00563)\end{array}$ & $\begin{array}{l}0.000900 \\
(0.00379)\end{array}$ & $\begin{array}{c}0.00517 \\
(0.00315)\end{array}$ & $\begin{array}{c}0.00796^{* * *} \\
(0.00289)\end{array}$ & $\begin{array}{c}0.00549 \\
(0.00470)\end{array}$ \\
\hline Observations & 19,294 & 14,652 & 13,974 & 14,436 & 17,210 & 13,254 & 12,694 & 13,249 \\
\hline Adjusted $R^{2}$ & 0.695 & 0.919 & 0.914 & 0.790 & 0.064 & 0.011 & 0.063 & 0.110 \\
\hline
\end{tabular}

Standard errors in parentheses.

$* p<0.10, * * p<0.05, * * * p<0.01$

Notes: Panel A uses the stock volatility measure controlling for mean returns. Panel B uses our newspaper index based on "economic" terms. Panel C uses the newspaper index based on "commercial" terms. Standard errors are clustered at the year-month level. All of the uncertainty measures have been demeaned and scaled to result in a series with a standard deviation of 1 . So the coefficients for the uncertainty effect are comparable across uncertainty measures. All regressions include industry and year fixed effects as well as state specific seasonal trends. An observation is a month-year-establishment value.

Sources: Census of Manufactures (Department of Commerce), New Orleans Times Picayune.

the largest effects, if any, to be found among this group. We sort plants into size quartiles based on their January employment levels by industry. These quartiles are calculated yearly so the set of large plants may differ from year to year as well.

Results with our preferred specification are reported in Table 7. Each column corresponds to a quartile of the employment distribution going from smallest to largest and the rows to the different measures of uncertainty. For now, we only report the results with the contemporaneous measures of uncertainty and ignore possible lagged effects. Somewhat surprisingly, the null effect reported earlier is not due to a composition bias of positive and negative effects for different size quartiles. All quartiles appear to be unaffected by these changes in uncertainty. It 
TABLE 8

EFFECTS OF LONG'S ASSASSINATION ACROSS PLANT SIZE QUARTILES AS MEASURED BY EMPLOYMENT COUNT IN JANUARY OF GIVEN YEAR

\begin{tabular}{lcccc}
\hline \hline & \multicolumn{4}{c}{ Log Wage Earners } \\
\cline { 2 - 5 } Employment Size Quartile & Bottom & Second & Third & Top \\
\hline Before assassination & -0.0805 & -0.0113 & -0.0170 & $0.111^{* * *}$ \\
& $(0.0551)$ & $(0.0491)$ & $(0.0324)$ & $(0.0380)$ \\
Observations & 4,466 & 3,237 & 3,222 & 3,157 \\
Adjusted $R^{2}$ & 0.081 & 0.026 & 0.013 & 0.011 \\
\hline
\end{tabular}

Standard errors in parentheses.

$* p<0.10, * * p<0.05, * * * p<0.01$

Notes: Results use the first coding of the Long indicator counting September 1935 as postassassination. All regressions include industry and state fixed effects. Standard errors are clustered at the month-level. An observation is a month-year-establishment value.

Sources: Census of Manufactures (Department of Commerce).

is important to emphasize again that the effects are not only small but precisely estimated across the three separate measures of uncertainty. ${ }^{11} \mathrm{It}$ will be interesting to compare these results to the event study of Long's assassination we present later.

Following some suggestive work in Bogart (2015) on the East India Company, we examine whether the effects are different across establishments of different sizes. The hypothesis is that the largest concerns will have closer connections to the regime making them most sensitive to changes in the political climate. Table 8 reports the effect of Long's assassination across quantiles of plant size based on a plant's January employment. Unlike the baseline case, there is statistically significant evidence that the largest plants benefited under Long's governorship while there is some evidence, although results are not statistically significant, that the smallest plants were hurt. This is consistent with the view that the largest establishments were able to develop a symbiotic relationship with Long that was rendered useless when he met his demise.

\section{CONCLUSION}

If political uncertainty mattered somewhere or sometime, it should have mattered in the Depression. Many accounts of policy uncertainty in the Depression have focused on the case of FDR's New Deal which was

\footnotetext{
${ }^{11}$ We would have liked to also conduct the analysis for particular industries such as oil refining, which was a major Long target. However, much of the oil refined in Mississippi would be shipped from Louisiana and so would not serve as an effective control.
} 
truly ambitious, experimental, and, thus to critics, uncertain. However, it is difficult to disentangle the multitude of factors that combined to create the Depression from the, perhaps inevitable, policy changes attempted to mitigate the Depression. Rather than focusing on the aggregate time series, we considered a "natural experiment" on the effects of local policy uncertainty generated by the near absolute rule of Huey Long over the state of Louisiana in the 1930s. Using uncertainty measures specific to Louisiana, we tested for the effect of political uncertainty using employment data from the Census of Manufactures with the state of Mississippi serving as a control. Overall, we find little effect from uncertainty on manufacturing employment in Louisiana. These are particularly striking results as Long's tenure presents something of an upper bound on the effects of uncertainty, in our view. The results seem to cast some doubt on the effects of the relatively more moderate FDR who did not operate with anything close to the near absolute power that Long exercised over Louisiana.

Perhaps the focus on political uncertainty per se has been misplaced. ${ }^{12}$ Instead the focus should be on the crony capitalism often associated with uncertain times and powerful leaders. There were any number of large establishments in Louisiana at this time looking to cash in on their connections to Long. One of Long's most loyal backers was Robert S. Maestri, a major New Orleans landowner and one of the wealthiest men in the city (Williams 1981, pp. 97, 252-53). Or consider the case of the shrimp industry. In 1932, the Louisiana legislature considered a bill limiting working hours for women to eight hours a day. This was the sort of legislation that Long typically supported. In this case, however, Long had the bill killed, since one his supporters owned a large shrimppacking establishment which would have suffered from the limitation on working hours (Hair 1991; Sanson 2006). "All over the state Long had supporters like the Fishers [owners of several major companies involved in furs, fishing, shrimping, and canning] or Savoie [a family which dominated Assumption parish both economically and politically]" (Williams 1981, p. 261). The unexpected assassination of Long in 1935 provides a potentially very valuable case study to place alongside the work of Baker, Frydman, and Hilt (2014) on the assassination of President McKinley, Jones and Olken (2009) on attempted assassinations of leaders more generally, and Thomas Ferguson and Voth (2008) on political connections in Hitler's Germany.

\footnotetext{
${ }^{12}$ Note that our results have nothing to say about the role of economic uncertainty more generally.
} 


\section{REFERENCES}

Alexopoulos, Michelle, and Jon Cohen. "Uncertain Times, Uncertain Measures." Unpublished Manuscript. University of Toronto, 2009.

Amenta, Edwin, Kathleen Dunleavy, and Mary Bernstein. "Stolen Thunder? Huey Long's 'Share Our Wealth,' Political Mediation, and the Second New Deal." American Sociological Review 59, no. 5 (1994): 678-702.

Baker, Richard B., Carola Frydman, and Eric Hilt. "From Plutocracy to Progressivism? The Assassination of President McKinley as a Turning Point in American History." Unpublished Manuscript, Boston University, 2014.

Baker, Scott R., and Nicholas Bloom. "Does Uncertainty Reduce Growth? Using Disasters as Natural Experiments." NBER Working Paper No. 19475, Cambridge, MA, 2013.

Baker, Scott R., Nicholas Bloom, and Steven J. Davis. "Measuring Economic Policy Uncertainty." NBER Working Paper No. 21633, Cambridge, MA, 2015.

Basu, Susanto, and Brent Bundick. "Uncertainty Shocks in a Model of Effective Demand.” NBER Working Paper No. 18420, Cambridge, MA, 2012.

Baxter, Marianne, and Robert G. King. "Measuring Business Cycles: Approximate Band-Pass Filters for Economic Time Series." Review of Economics and Statistics 81, no. 4 (1999): 575-93.

Bernanke, Ben S. "Irreversibility, Uncertainty, and Cyclical Investment." Quarterly Journal of Economics 98, no. 1 (1983): 85-106.

Bertola, Giuseppe, Luigi Guiso, and Luigi Pistaferri. "Uncertainty and Consumer Durables Adjustment.” Review of Economic Studies 72, no. 4 (2005): 973-1007.

Binder, John. "The Event Study Methodology Since 1969." Review of Quantitative Finance and Accounting 11 (1998): 111-37.

Bittlingmayer, George. "Output, Stock Volatility, and Political Uncertainty in a Natural Experiment: Germany, 1880-1940.” The Journal of Finance 53, no. 6 (1998): 2243-57.

Bloom, Nicholas. "The Impact of Uncertainty Shocks." Econometrica 77 (2009): 623-85.

Bloom, Nicholas, Max Floetotto, Nir Jaimovich, et al. "Really Uncertain Business Cycles.” NBER Working Paper No. 18245, Cambridge, MA, 2012.

Bogart, Dan. “"There Can Be No Partnership with the King': Regulatory Uncertainty and Investment in the English East India Company." Unpublished Manuscript, UC-Irvine, 2015.

Born, Benjamin, and Johannes Pfeifer. "Policy Risk and the Business Cycle." Journal of Monetary Economics 68 (2014): 68-85.

Brinkley, Alan. Voices of Protest: Huey Long, Father Coughlin, and the Great Depression. New York: Random House, 1983.

Federer, J. Peter, and David A. Zalewski. "Uncertainty as a Propagating Force in the Great Depression.” Journal of Economic History 54, no. 4 (1994): 825-49.

Ferguson, Thomas, and Hans-Joachim Voth. "Betting on Hitler: The Value of Political Connections in Nazi Germany." Quarterly Journal of Economics 123, no. 1 (2008): 101-37.

Fernández-Villaverde, Jesús, Pablo Guerrón, Juan F. Rubio-Ramírez, et al. "Risk Matters: The Real Effects of Volatility Shocks." American Economic Review 101, no. 6 (2011): 2530-61. 
Fineran, John N. Career of a Tinpot Napoleon: Political Biography of Huey P. Long. Baton Rouge, LA: Claitors Pub Div., 1986.

Fishback, Price V., and Valentina Kachanovskaya. "In Search of the Multiplier for Federal Spending in the States During the Great Depression." NBER Working Paper No. 16561, Cambridge, MA, 2011.

Hair, William Ivy. The Kingfish and His Realm. Baton Rouge, LA: Louisiana State University Press, 1991.

Higgs, Robert. "Regime Uncertainty: Why the Great Depression Lasted So Long and Why Prosperity Resumed after the War.” Independent Review 1 (Spring 1997): 561-90.

Holmes, Thomas J. "The Effects of State Policies on the Location of Industry: Evidence from State Borders." Journal of Political Economy 106, no. 4 (1998): 667-705.

Jones, Benjamin F., and Benjamin A. Olken. "Do Leaders Matter? National Leadership and Growth Since World War II." Quarterly Journal of Economics 120, no. 3 (2005): 835-64.

- "Hit or Miss? The Effect of Assassinations on Institutions and War." AEJ: Macroeconomics 1, no. 2 (2009): 55-87.

Leduc, Sylvain, and Zheng Liu. "Uncertainty, Unemployment, and Inflation.” FRBSF Economic Letter 28, San Francisco, CA, 2012.

Libecap, Gary D. "The Political Economy of Crude Oil Cartelization in the United States, 1933-1972.” Journal of Economic History 49, no. 4 (1989): 833-55.

Lucas, Robert E., Jr. "Milliman Lecture.” University of Washington, Seattle, WA, 2011.

Mathy, Gabriel. "How Much Did Uncertainty Shocks Matter in the Great Depression?" American University Working Paper, Washington, DC, 2014.

—. "Stock Volatility, Return Jumps and Uncertainty Shocks During the Great Depression." Financial History Review 23, no. 2 (2016): 165-92.

Mayer, Thomas, and Monojit Chatterji. "Political Shocks and Investment: Some Evidence from the 1930s." Journal of Economic History 45, no. 4 (1985): 91324.

Nakamura, Emi, and Jón Steinsson. "Fiscal Stimulus in a Monetary Union: Evidence from U.S. Regions." American Economic Review 104, no. 3 (2014): 753-92.

Pastor, Lubos, and Pietro Veronesi. "Uncertainty about Government Policy and Stock Prices." Journal of Finance 67, no. 4 (2012): 1219-64.

Romer, Christina D. "The Great Crash and the Onset of the Great Depression." Quarterly Journal of Economics 105, no. 3 (1990): 597-624.

Sanson, J. P. "“What He Did and What He Promised to Do...": Huey Long and the Horizons of Louisiana Politics." Louisiana History: The Journal of the Louisiana Historical Association 47, no. 3 (2006): 261-76.

Schlesinger, Arthur M. The Politics of Upheaval: 1935-1936, The Age of Roosevelt. Geneva, IL: Houghton Mifflin Harcourt, 2003.

Schumpeter, Joseph A. Capitalism, Socialism and Democracy. New York: Harper and Row, 1942.

Schwert, G. William. “Why Does Stock Market Volatility Change Over Time?” Journal of Finance 44, no. 5 (1989): 1115-53.

Shoag, Daniel, and Stan Veuger. "Uncertainty and the Geography of the Great Recession." Journal of Monetary Economics, Forthcoming.

Summers, Larry. "Donald Trump Is a Serious Threat to American Democracy." Washington Post Wonkblog, 1 March 2016. 
Sutch, Richard, and Susan Carter (Eds.). Historical Statistics of the United States. New York: Cambridge University Press, 2000.

U.S. Department of the Census. "Personal Income and Personal Income Per Capita by State: 1929 to 2001." Statistical Abstract of the United States: 2003 35(HS) (2003): 111-37.

Voth, Hans-Joachim. "Stock Price Volatility and Political Uncertainty: Evidence from the Interwar Period." Massachusetts Institute of Technology Discussion Paper, Cambridge, MA, 2002.

Wallis, John Joseph. "Employment in the Great Depression: New Data and Hypotheses." Explorations in Economic History 26, no. 1 (1989): 45-72.

White, Richard. Kingfish: The Reign of Huey P. Long. New York: Random House, 2006.

Williams, T. Harry. Huey Long. New York: Vintage Books, 1981.

Ziebarth, Nicolas L. "Identifying the Effects of Bank Failures from a Natural Experiment in Mississippi During the Great Depression." AEJ: Macroeconomics 5, no. 1 (2013): 81-101.

- "The Great Depression through the Eyes of the Census of Manufactures." Historical Methods 48, no. 4 (2015): 185-94 . 